\section{ALBERT SERRA'S THE DEATH OF LOUIS XIV (2016) ACCORDING TO DELEUZE'S CONCEPT OF AFFECTION-IMAGE} LKHAGVADULAM PUREV-OCHIR

\begin{abstract}
This paper will conceptually apply and analyze Gilles Deleuze's concept of affection-image, using The Death of Louis XIV (2016), to determine what the affection-image depicts and how it depicts it. Deleuze's concept is singular in its reconceptualization of the close-up shot where he removes the dimensions, i.e. size and scale, of the shot from its definition and instead argues that the meaning of the shot depends upon the value (quality and power) it manifests. Deleuze calls this value 'the affect', and 'the affect' is the singular requirement for an image to be categorized as affection-image.
\end{abstract}

I chose Albert Serra's The Death of Louis XIV to apply and analyze the affection-image because it is a film largely reliant on close-up shots and is a great example of a modern day 'affective film'. Specifically, I shall study the moments and instances where affection-image materializes in The Death of Louis XIV. I determined that there are three notable instances where Deleuze's concept plays out: firstly, affection-image as failed action-image; secondly, affection-image as any-space-whatever; and thirdly, affection-image as degradation to impulse-image.

Deleuze's concept of the affection-image may encompass shots that are commonly known as medium and wide shots. The affection-images in The Death of Louis XIV create, in aesthetic arrangement with other images, a poignant and wry memento mori about the futility of power in the face of death, and about the banality of death and its ceremonies.

Keywords: the face, the close-up, the affection-image, The Death of Louis XIV 


\section{Introduction}

In the selfie-obsessed visual culture of today, the image of the face has seemingly acquired a frozen, facetious quality devoid of its traditional emotive, expressive, and emblematic qualities. Throughout history, the face played big roles in art and aesthetics, in religion and spirituality, and in science and medicine. An entire range of ideas and emotions can be conjured when one thinks of the faces of Jesus, Nefertiti, Mona Lisa, etc. But of all the depictions of the face, none has had a stronger, more personal, and more powerful effect than the close-up shot of the face in the newest of plastic arts, cinema.

Since the beginning of cinema, the concept of the close-up shot, particularly that of a face, was met with scrutiny and awe. From psychoanalysis and linguistics to empirical and cognitive film studies, a range of film theory has studied the role of the close-up shot in relation to editing, cinematography, narratology, acting, and mise-en-scene. In the following paragraphs, I shall shortly divulge on the major areas where the close-up shot has been studied and subsequently reinforce my choice and objective of analyzing Deleuze's concept.

Surprisingly, early film viewers were horrified of the close-up. It had a startling effect on viewers conditioned to watch theater and who saw cinema as an extension of the theatrical experience.
Early filmmakers were reluctant to move the camera close to its subjects. (According to Lillian Gish, a flustered producer on D.W. Griffith's film had said, "We pay for the whole actor, Mr. Griffith. We want to see all of him" [GISH, 1970]) Nevertheless, the unparalleled graphic value of the close-up shot was increasingly realized as narrative cinema developed.

Film theorician Mary-Ann Doanne studies the close-up in relation to cinematic scale as dialectic of the real and the unreal. Speaking of early $20^{\text {th }}$ century films, Doanne points out the trauma of scale caused by a monstrous close-up and how the close-up image in the early days was depicted as a sign outside of the narrative space (reality) in order to contain the disorientation. Another way to mollify the effect was to have a continuous change in scale, where the subject slowly moved closer to the camera (DOANNE, 2008).

Ironically, the close-up became the primary vehicle for the popularity of Hollywood films, particularly its star system. Early theoricians like Balazs and Epstein extolled the close-up shot as the singular 'technical condition for cinematic art' (BALAZS, 1970) and the 'soul of cinema' (EPSTEIN, 1977). Soviet cinema, in opposition to Hollywood films, designated the close-up as an element of intellectual, critical cinema, as exemplified in the Kuleshov Effect. For Sergei Eisenstein, the close-up was a montage-unit, whose meaning was dependent on the juxtaposition of images. Its power lay in the absolute change of dimensions where a magnified cockroach is more intimidating than a hundred elephants in wide shot (EISENSTEIN, 1995). The focus on linguistics in 1970's film theory identified the close-up as a cinematic synecdoche, in line with the approach of the Soviets. The close-up shot is a sign which has power in relation to the whole. It is intrinsically linked to editing.

Walter Benjamin utilizes the close-up shot as an example to his argument on capitalism and commodity, how the close-up is an element of capitalist desire of the masses for closeness, for possession and possessiveness. He points out the spectator's place within the cinematic scene where the close-up comforts a subconscious need to possess something, even if said thing is a replication or a reproduction (BENJAMIN, 1969).

In the area of gender studies, the closeup shot is intimately linked to the fetishized image of the female body on screen. The close-up shot fragments and objectifies her body, taking her subjective power out of the narrative space (MULVEY, 1975). A proliferation of closeups may ideologically isolate and alienate female protagonists from a field of action and context (ROOF, 1999).

Cognitive psychologists suggest that the close-up mimics the way the brain 
works. The close-up shot, particularly that of a face, is a cinematic device which cues identification and empathy in the viewers. It resembles the brain's activity of paying attention by focusing on an image and is crucial in keeping the viewers involved on the events of the film. (MUNSTERBERG, 2012)

My research on the close-up shot has led me to conclude that of all the literature on the close-up shot, philosopher and film critic Gilles Deleuze's concept of 'affection-image' brings, as I can see, the freshest angle on how to approach the close-up. Deleuze defines the closeup, or what he calls as affection-image, based on the shot's phenomenological function, instead of on its scale and dimension. The affection-image is less a technical term and more a basic element for the understanding of film art. Deleuze's concept expands the close-up shot to a more inclusive and philosophical dimension. According to Deleuze, affection-image creates values of thought and emotion, which transcend the action of the film and reveal virtual truths.

Gilles Deleuze is one of the foremost influential philosophers of the $20^{\text {th }}$ century. He combines philosophy with film criticism in his notoriously obscure books on the art of cinema - Cinema 1: Movement Image (1983) and Cinema 2: Time Image (1985). The concept of the affection-image is from his first Cinema book and is one of four basic elements of movement image, or "the acentered set [ensemble] of variable elements which act and react on each other (DELEUZE, 1997, 217). In Deleuze's philosophy, the world is the accumulation of movement-images, divided into four categories: perception-image, affection-image, impulse-image, and action-image.

\section{An approach to The Death of Louis XIV}

\section{The Film}

I will be analyzing the close-up shots in Albert Serra's The Death of Louis XIV (2016) according to Deleuze's definition of the affection-image, particularly the ways in which the aesthetic arrangement of the affection-image in relation to other images create a poignant and wry memento mori about the futility of power in the face of death and about the banality of death and its ceremonies. In The Death of Louis XIV, Albert Serra's usage of close-up shots to reveal and speculate grander truths about life and death is a potent example of Deleuze's affection-image and its phenomenological function in cinema.

The Death of Louis XIV is a historical drama depicting the last days of the Sun King's life, a period when Louis XIV, poignantly portrayed by Jean-Pierre Leaud, succumbs to the slow rotting of his flesh despite the many interventions of his court, and ultimately perishes of gangrene. While the doctors struggle to treat the King, the King struggles to uphold and execute the power he bears. The affection-images in the film, mostly consisting of the face of Jean-Pierre Leaud, elevate these struggles to a shared experience and incite thoughts about death and its non-discriminating grip over kings and paupers alike.

Director Albert Serra is the current 'enfant terrible' of European cinema. He was born in Girona, Catalonia in 1975. He came to prominence with his first feature Honor of the Knights (2007), a film selected by Cahiers du Cinema as one of the ten best films of 2007. Serra calls his films as performance artwork and utilizes unusual filming techniques such as using more than one camera and never working with professional actors. In an interview, Serra admits to choosing to work with Jean-Pierre Leaud in The Death of Louis XIV because he finds Leaud to be a 'pure' and 'uncorrupted' human being despite Leaud's being a celebrated actor (FAIRFAX, 2003). The film was shot in fifteen days and amassed hundreds of hours of (improvisational) footage. Regarding The Death of Louis XIV, Serra states,

"The meaning of the film has to emerge from the set, not from me. I shoot long takes, never repeating the same take, never rehearsing with the actors, and never making variations. I don't have monitor on set. I never 


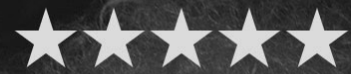 \\ "Quietly amazing" \\ Peter Bradshaw, THE GUARDIAN}

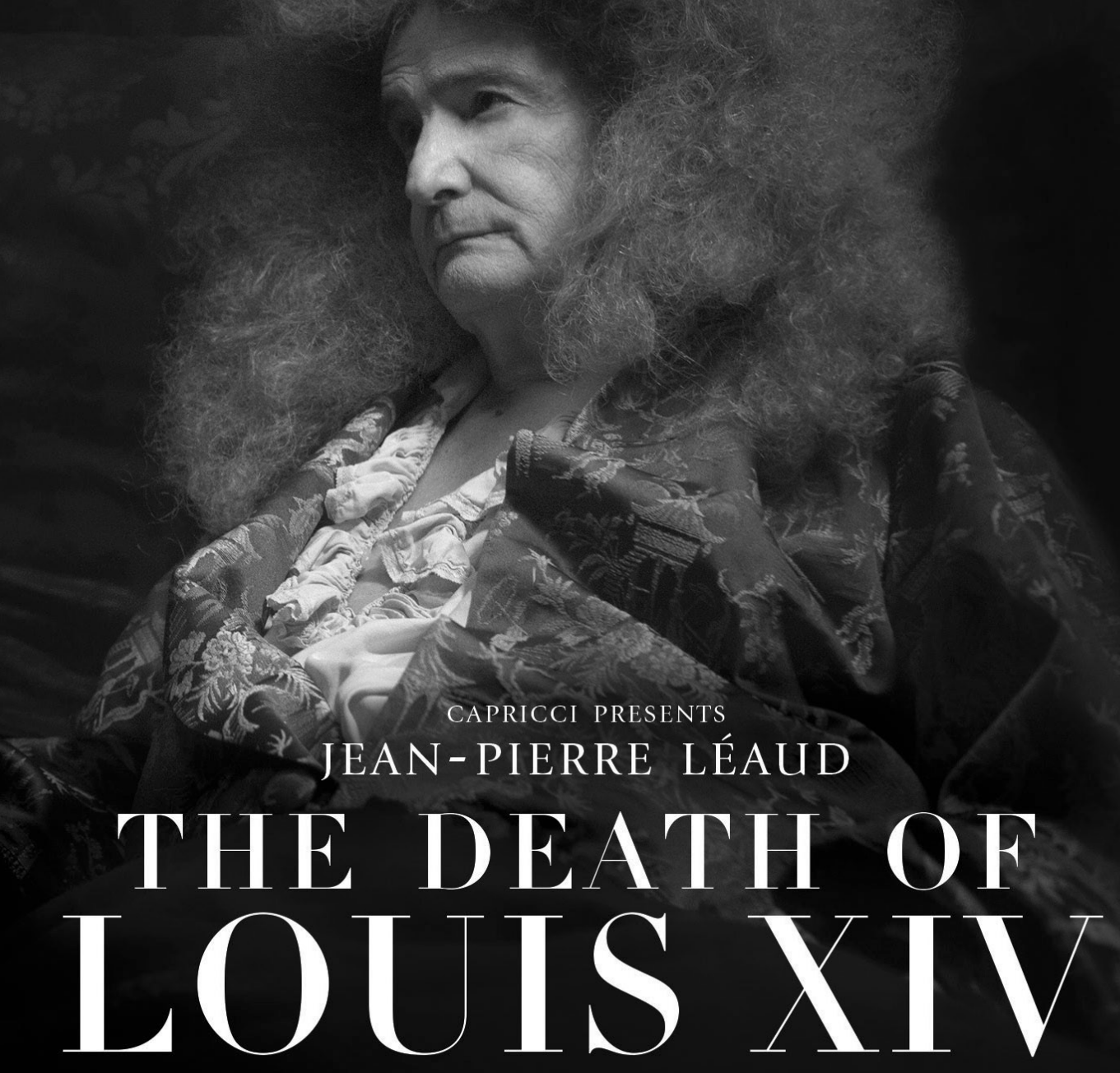

A FILM BY ALBERT SERRA 
look at an image from the film before the end of the shooting. This creates an atmosphere where these magical things will appear in the performance" (AGUILAR, 2017).

From hundreds of hours of footage from three cameras, Serra selected hundred and fifteen minutes of moving images. It is intriguing that most of these images are close-up shots, as well as reveal the distinctive characteristics of Deleuze's concept of affection-image. I humbly conclude that The Death of Louis XIV is an 'affective' film par excellence of its time, on level with the brilliance of Dreyer's The Passion of Joan of Arc (1928).

\section{Affection Image}

Deleuze's concept of the affection image starts with the concept of the face and its role in physiology and physiognomy. He posits the face as having the exact opposite role as that of vision. While vision is an afferent nerve where sensors move from the periphery of the body to the central nervous system, the facial muscles, like all muscles in the body, are efferent, meaning that sensors move from the central nervous system to the outside. Facial movement originates in the central nervous system and results as expression on the face. However, compared to other muscles in the body, the facial muscles are mostly immobile; they cannot complete tasks like other muscles can. Facial muscles are extremely subtle and miniscule in their motions.

On the other hand, the face is an area where sensory input is maximized because it is populated by the sensory organs: eyes, nose, ears, and mouth. It is an area of intense sensory experience that leads to a series of micro-movements that is the facial expression.

Therefore, Deleuze calls the face "an organ-carrying plate of nerves which has sacrificed most of its global mobility and which gathers or expresses in a free way all kinds of tiny local movements which the rest of the body usually keeps hidden" $(1997,88)$. The key word in this definition is 'hidden'. The face reveals that which is hidden. It is not active but affective. The face answers two questions: "What are you thinking about?" (the face as reflective plate), and "What do you sense or feel?" (the face as a series of micro-movements).

Deleuze draws a table to describe the dual characteristics of the face:

As we see, the face is two things: firstly, a reflective surface, and secondly, a series of small, expressive movements. Deleuze's singular approach to what is commonly known as the 'close-up shot' is revealed in this binary definition of the face: anything that is at once reflective and intensive, at times one more than the other, is a face. It has the qualities of a 'face', and it has 'affect'. According to Deleuze, "there is no close-up of the face, the face is in itself close-up, the close-up is by itself face and both are affect, affection-image" (1997, p.88).

\begin{tabular}{|l|l|}
\hline Reflective face & Intensive face \\
\hline Sensible nerve & Motor tendency \\
Immobile receptive plate & Micro-movements of expression \\
Faceifying outline & Characteristics of faceicity \\
Reflecting unity & Intensive series \\
Wonder (admiration, surprise) & Desire (love-hate) \\
Quality & Power \\
Expression of a quality common to several things & Expression of a power which passes from one quality to another \\
\hline
\end{tabular}

Table 1. Deleuze's table for the two poles of the face. 
In other words, an image having the qualities of a face is an affection-image because it reveals, through reflection and intensity, a quality or power that is hidden underneath the surface. A face, like that of Dreyer's Joan of Arc, is an affection-image, but so is a subtle landscape like the burning barn in Tarkovsky's The Mirror (1975). Both images do not carry out any actions; they serve to impart certain affects. These affection images reveal the underlying ideas and themes in each film: the passion of Joan of Arc and the destruction of family and traditional roles, respectively.

\section{The Affect}

The affect is not an action or a reaction, but a quality which arises in parallel. In terms of Hegelian dialectics, the affect is that which rises in parallel with the antithesis in the interaction between thesis and anti-thesis.

Thesis + antithesis synthesis

When thesis and antithesis collide, there rises an infinite number of possibilities before one synthesis is determined. The affect is this infinite number of possibilities. It is an entity independent of the antithesis or the synthesis, but it is not separate from them. The affect resides in the delay between these two elements.

In other words, when an object comes in contact with exterior stimuli, the object is transformed. The affect is the delay between the object and the transformed object. It is not action or reaction, but a quality of having been transformed. It is power as expressed.
Deleuze relies on C.S. Peirce's classification of images into 'firstness' and 'secondness' to explain the elusiveness of the affect. Deleuze determines the affection-image to have the same qualities of firstness.

"Peirce does not conceal the fact that firstness is difficult to define, because it is felt, rather than conceived: it concerns what is new in experience, what is fresh, fleeting and nevertheless eternal... these are qualities or powers considered for themselves, without reference to anything else, independently of any question of their actualization. It is that which is as it is for itself and in itself. It is, for example, a 'red', as present in the proposition 'this is not red' as in 'this is red'... It is not a

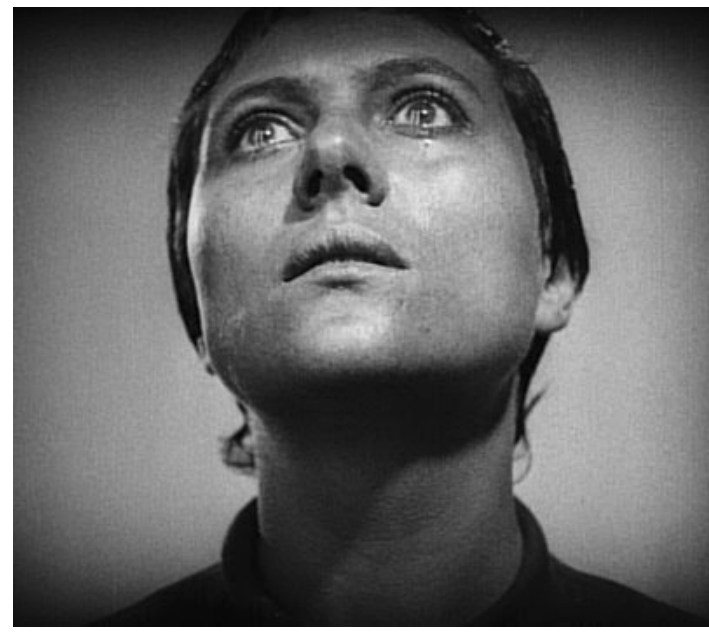

Figure 2. Image from Dreyer's The Passion of Joan of Arc (1928)

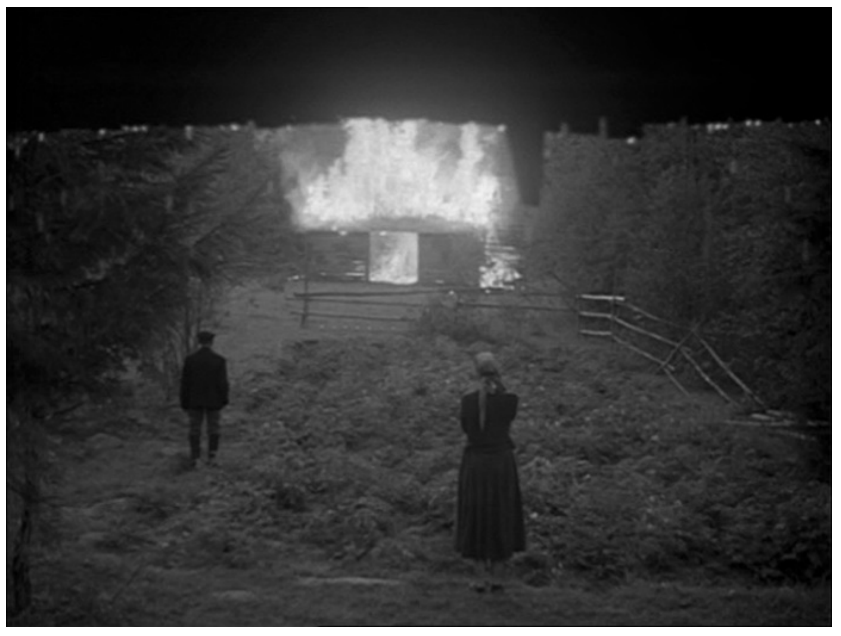

Figure 3. Image from Tarkovsky's The Mirror (1975) 
sensation, a feeling, an idea, but the quality of a possible sensation, feeling or idea. Firstness is thus the category of the Possible: it gives a proper consistency to the possible, it expresses the possible without actualizing it, whilst making it a complete mode. Now, this is exactly what the affection-image is: it is quality or power, it is potentiality considered for itself as expressed" (DELEUZE, 1997, 98).

In the above statement, Deleuze means to say that the affect is an individual quality full of possibilities that is yet to be actualized with action. To kill is an action. Dead is an actualized state or situation. Death is a concept. However, dying is a possibility; it is in motion; it is a quality of being, an experience, a fluid power. Dying is a quality that is as true in the statement ' $\mathrm{He}$ is dying' as in the statement ' $\mathrm{He}$ is not dying'. It is unactualized. As I can see, this is where the affection-image lingers, in the quality or power of constant transformation and movement.

Although the affection-image is in aesthetic arrangement with other images, it is an individual entity. The reason the affection-image is individual, but not separate, of other images lies in the affection-image's ability to abstract spatio-temporal coordinates. The affection-image is timeless and space-less. It abstracts and elevates an action-image to a different dimension. Deleuze extensively uses film critic Bela Balazs's analysis of the face in close-up to exemplify how the affect is separate from other images and spatio-temporal coordinates.

"The expression of an isolated face is a whole which is intelligible by itself. We have nothing to add to it by thought, nor have we anything to add to that which is of space or time. When a face that we have just seen in the middle of a crowd is detached from its surroundings, put into relief, it is as if we were suddenly face to face with it. Or furthermore if we have seen it before in a large room, we will no longer think of this when we scrutinize the face in a closeup. For the expression of a face and the signification of this expression have no relation or connection with space. Faced with an isolated face, we do not perceive space. Our sensation of space is abolished. A dimension of another order is opened to us" (DELEUZE, 1997, 96)

Because the affection-image is devoid from spatio-temporal coordinates, it is not an enlarged image, or an image of a partial object torn away from a body source. The affection-image is not a closeup of a far away object, or a portion of a whole. The image of a face is not an image of a head connected to a body, but an independent image with a quality considered for itself as expressed. "The close-up is not an enlargement and, if it implies a
A)

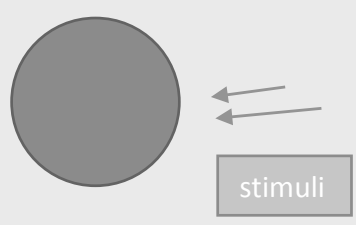

B)

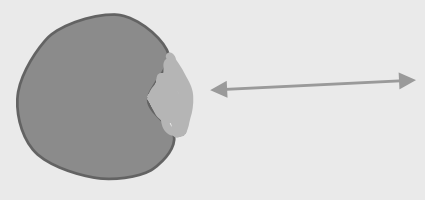

reaction to

stimuli
C)

The delay

between $A$ and

$B$ is 'the affect'.

Figure 4. $\mathrm{A}$ is the object, while $\mathrm{B}$ is the transformed object. $\mathrm{C}$ is 'the affect' or quality which rises parallel to the transformed object. 
change of dimension, this is an absolute change, a mutation of movement which ceases to be translation in order to become expression" (DELEUZE, 1997, 96).

In order to make Deleuze's concepts more transparent, I shall apply them to the film The Death of Louis XIV (2016). Director Albert Serra on the depiction of Louis XIV in the film:

"But when you get closer to the king himself, it's quite mysterious. It's abstract, you know. This mystery, for me, has to do with this abstraction of absolute power. What is the interest of absolute power? This is the main point. Here, he has to face mortality, and he has to face very quotidian problems, but still what is the goal of absolute power? To keep on with this absolute power?" (YEPES, 2017).

The Death of Louis XIV questions the meaning of absolute power - the absolute power of the King as well as the absolute power that is death. Serra attempts to answer his question with an effective deployment of affection-images that illuminate the slow-paced situations and ambiguous actions of the characters within the film.

Three notable elements in the content and style of the film can be pointed out to describe the use of affection-images within The Death of Louis XIV: firstly, affection-image as failed action-image; secondly, affection-image as any-space-whatever; and thirdly, affection-image as degradation to impulse-image.

\section{Affection-image as failed action-image}

Singular expressions on the face of the Sun King and on the faces of his courtiers materialize in the aftermath of action-images and 'define' the scene, imbuing it with quality or meaning. But first, what is an action-image?

"When qualities and powers are apprehended as actualized in states of things, in milieu which are geographically and historically determinable, we enter into the realm of the action-image. The realism of the action-image is opposed to the idealism of the affection-image" (DELEUZE, 1997, 123).

In other words, the action-image takes place in a specific and determinate space-time, like Louis XIV's reign, where characters, such as the Sun King and his courtiers, behave accordingly to their roles within that space-time. Louis XIV was the absolute embodiment of power on earth, the earthly representation of God. The film follows this decorum. Everyone surrounding the Sun King tiptoes around him and speaks in hushed voices. Serra is meticulous with art and costume design. The King is always exquisitely robed, complete with a towering wig. The mannerisms and decorum of the king's court are realistic and detailed. The action-images in the film portray a court that is working accordingly to how it should work: the King giving orders and the court running to serve him.

Deleuze describes classical Hollywood films, such as the western and film noir, as a cinema which triumphs the action-image:

"The milieu and its forces incurve on themselves, they act on the character, throw him a challenge, and constitute a situation in which he is caught. The character reacts in his turn (action properly speaking) so as to respond to the situation to modify the milieu or his relation with the milieu, with the situation, with other characters... Out of this emerges a restored or modified situation, a new situation" (1997, 141-142).

In other words, in the realm of action-images, a protagonist faces a challenge that rises out of his/her environment. The protagonist must then utilize his/ her agency to fight the adversaries and create a new or restored environment. 
In the case of The Death of Louis XIV, there is a rogue element in the order of action-images: death. This rogue element does not arise from the milieu (the spatio-temporal coordinates) itself. Death is not an antagonist with which the King can fight with the means and agency that he has as King, as the protagonist of the film. The action-images break down and fail because of this rogue element.

Serra sets-up a situation that is impossible to be modified through the actions of the characters. There is not one character in the film who successfully fights 'death' as represented by the gangrene spots on the King's leg. On the contrary, the doctors are all bumbling fools who take turns poking and prodding the King and force feeding him different foods.

The action-images in the film revolve around the following dialectic:

The King is sick + the doctors treat him $=$ The King is sicker.

Instead of the action-images giving way to a new situation, they fail and degrade to an even worse state. This worsened state or quality is expressed, among other things, on the King's long-suffering, silent face. Instead of culminating in a new situation (with space-time coordinates), the dialectic of action and reaction culminates on the abstraction of the King's face.

Dyrk Ashton specifies the relationship between affection-image and action-image in his dissertation on Deleuze and cinema: "... affection-images possess 'power,' which can be regarded like potential energy. This potential energy is released and becomes 'force' in action-images" $(2006,127)$.

In the Death of Louis XIV, the potential energy in the affection-images are never released to become force and action.

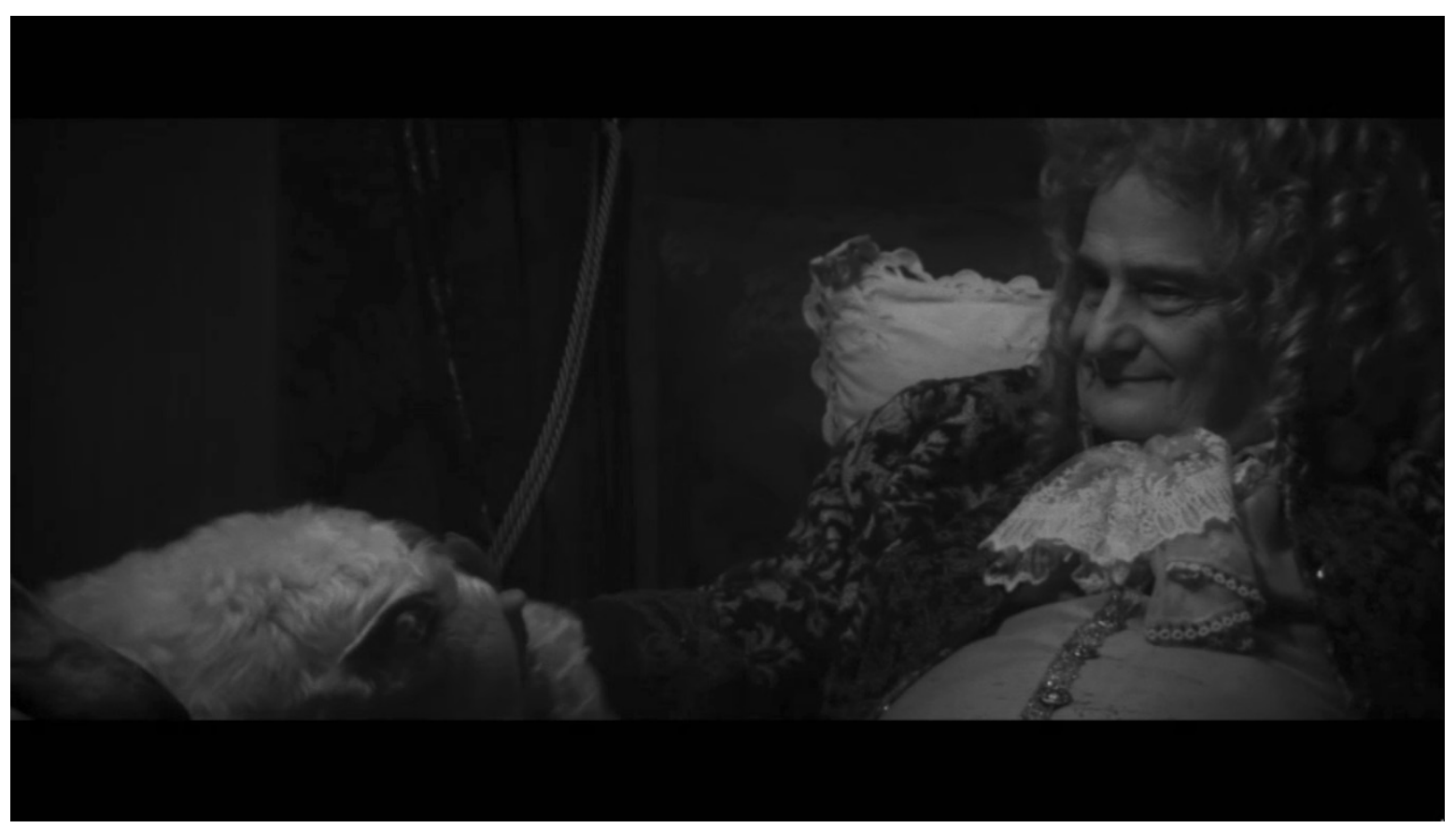

Figure 5. The King lovingly caresses his favorite dogs. 
As viewers, we are constantly expecting something to happen, particularly with each arrival of new doctors; instead, the doctors never achieve a potent solution, and we are constantly 'face to face' with the landscape of the (worsening) King's face. As I see it, Albert Serra speaks of the virtual quality of the face when he mentions the ambiguity surrounding the depiction of Louis XIV (YEPES quote on page 17). The up close and personal depiction of the King serves to express the quality of dying and its many facets, a constant transformation which happens before the viewers' eyes.
The (failed) action-images in the film portray a limited and castrated power where the King increasingly loses his executive powers. The affection-images (the face of the King) in the aftermath of action-images express the different intensities of dying. With this arrangement, it is safe to assume that director Albert Serra wishes to communicate to the audience the ultimate impotence of power and the helplessness of each human being when faced with death.

In the beginning scene of the film, the King partakes in an evening entertainment. While the court ladies giggle and confabulate in the background, the King lies in bed, solitary, placed horizontally in the frame, a visually inactive and passive figure. He is briefly animated by the arrival of the 'dogs that I love so much'. He kisses and embraces them fondly. An uncharacteristic pan, the only one in a film comprised of still frames, from the dogs to the King illustrates their bond. But the dogs are taken away as part of doctor's orders and the activity abruptly comes to an end. The King's face is impassive, but the muscles on his cheek twitch as he looks on silently. Because of his sickness, i.e. death, the King is unable to exercise his power to veto the doctors' orders. The action of the scene gives way to an 'affective'

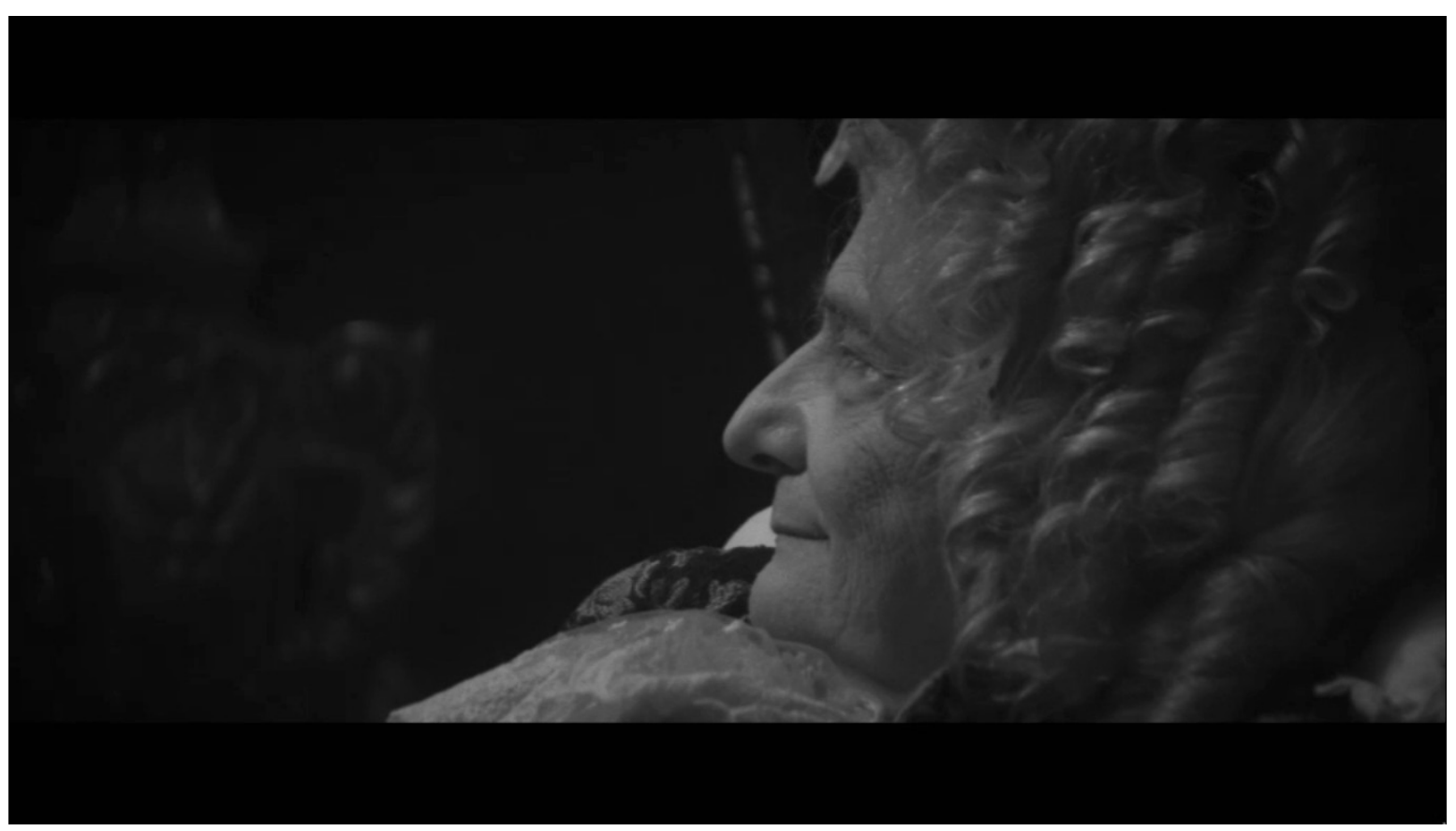

Figure 6. His favorite dogs are taken away. 
moment where the King's face imparts the quality of losing power. The King is losing his identity.

In this affective moment, the King seizes to be king and becomes a quality of an expressed. He is the pure expression of helplessness, the opposite of who he is in his determined milieu.

"Ordinarily, three roles of the face are recognizable: it is individuating (it distinguishes or characterizes each person); it is socializing (it manifests a social role); it is relational or communicating (it ensures not only communication between two people, but also, in a single person, the internal agreement between his character and his role). Now the face... loses all three in the case of close-up... The close-up is the face, but the face precisely in so far as it has destroyed its triple function..." (DELEUZE, 1997, 99).

In these affective moments, the King's face loses all three identifying characteristics and becomes the face of any old man, facing death. He could be a baker or a painter or a glass maker. The socio-cultural and political identity rooted in the action-images disappears, and the face of the King works to impart the subtleties of the inner life of a dying man. In The Deleuze Dictionary, PhD. Felicity J. Colman expounds on the affection-image,

"In its largest sense, affect is part of the Deleuzian project of trying to understand, and comprehend, and express all of the incredible, wondrous, tragic, painful, and destructive configurations of things and bodies as temporally mediated, continuous events. Deleuze uses the term 'affection' to refer

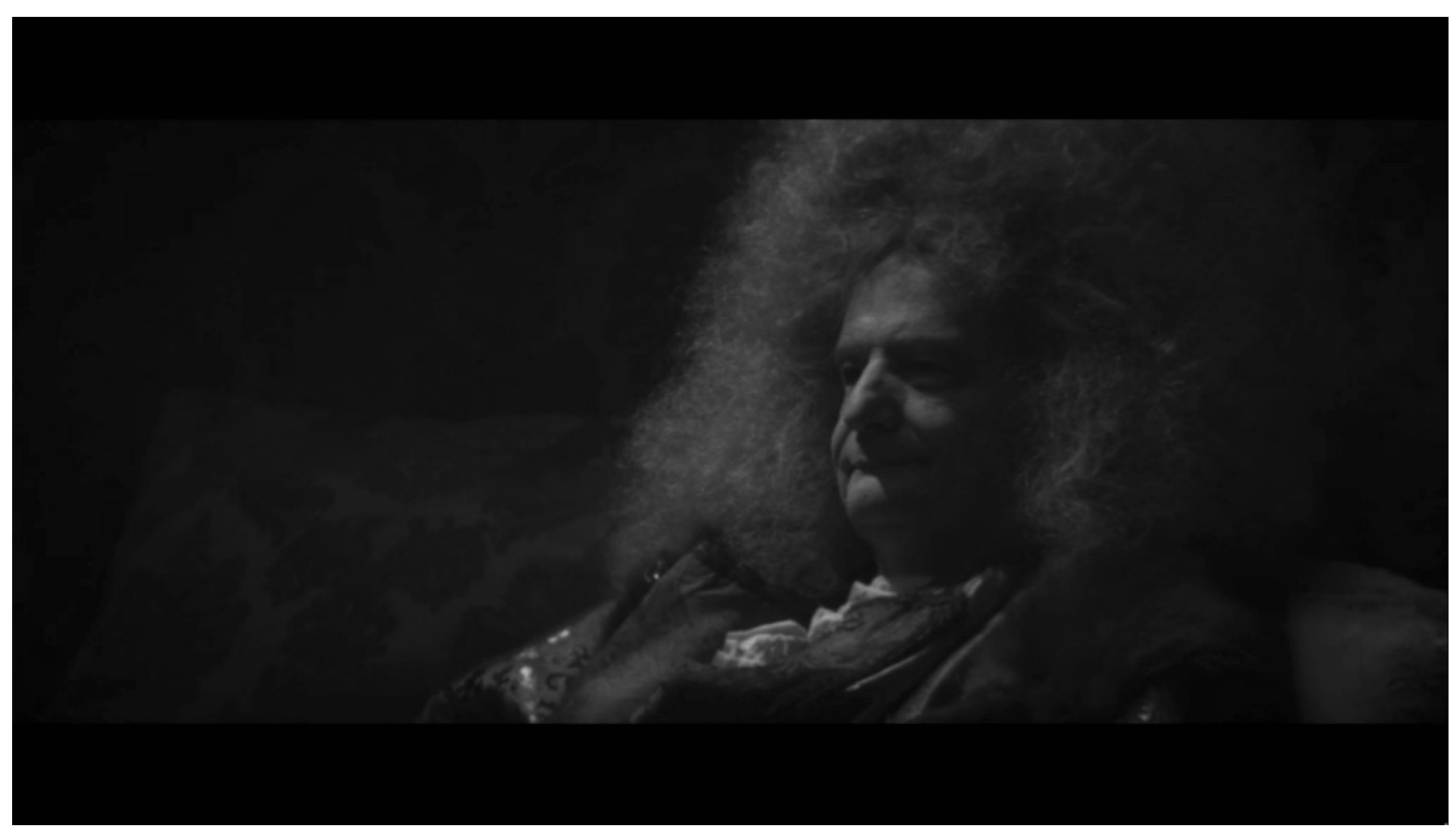

Figure 7. Ladies clap as the King swallows a morsel. 
to the additive processes, forces, powers, and expressions of change - the mix of affects that produce a modification or transformation in the affected body" (PARR, 2010, 11).

The face of the king reveals an ironic truth: dying is a transformative process for all human beings, and all the power, glory, and fame in the world cannot save us from death's grips, even if one is Louis XIV.

In another scene, when the King forces himself to eat an egg and a piece of biscuit in order to save face in front of the ladies of the court, the camera lingers on the King's face as his jaw chomps up and down. Serra holds the frame long enough that the perceived action becomes more than an activity, rather a reflection on helplessness. The court ladies clap, congratulating the King on his improved appetite and health. The action becomes a ludicrous activity, an empty rite, because he has neither appetite nor health. The King's motionless face, albeit smiling to the beaming court ladies, leads one to conclude ironic truths about power and its impotence.

"Sometimes the face thinks about something, is fixed on to an object...
In so far as it thinks about something, the face has value above all through its surrounding outline, its reflecting unity which raises all the parts to itself" (DELEUZE, 1997, 88). Just as Christ's face imparts the pure quality of spirituality and Joan's face (in Dreyer's Passion of Joan of Arc) imparts the multitude of intensity of Passion, the Sun King's face imparts the pure quality of impotence.

In another pivotal scene, the King admonishes his great-grandson who is the heir to the throne. He advises the child not to imitate him in his love for buildings and war. He urges him to make peace with his neighbors and give back

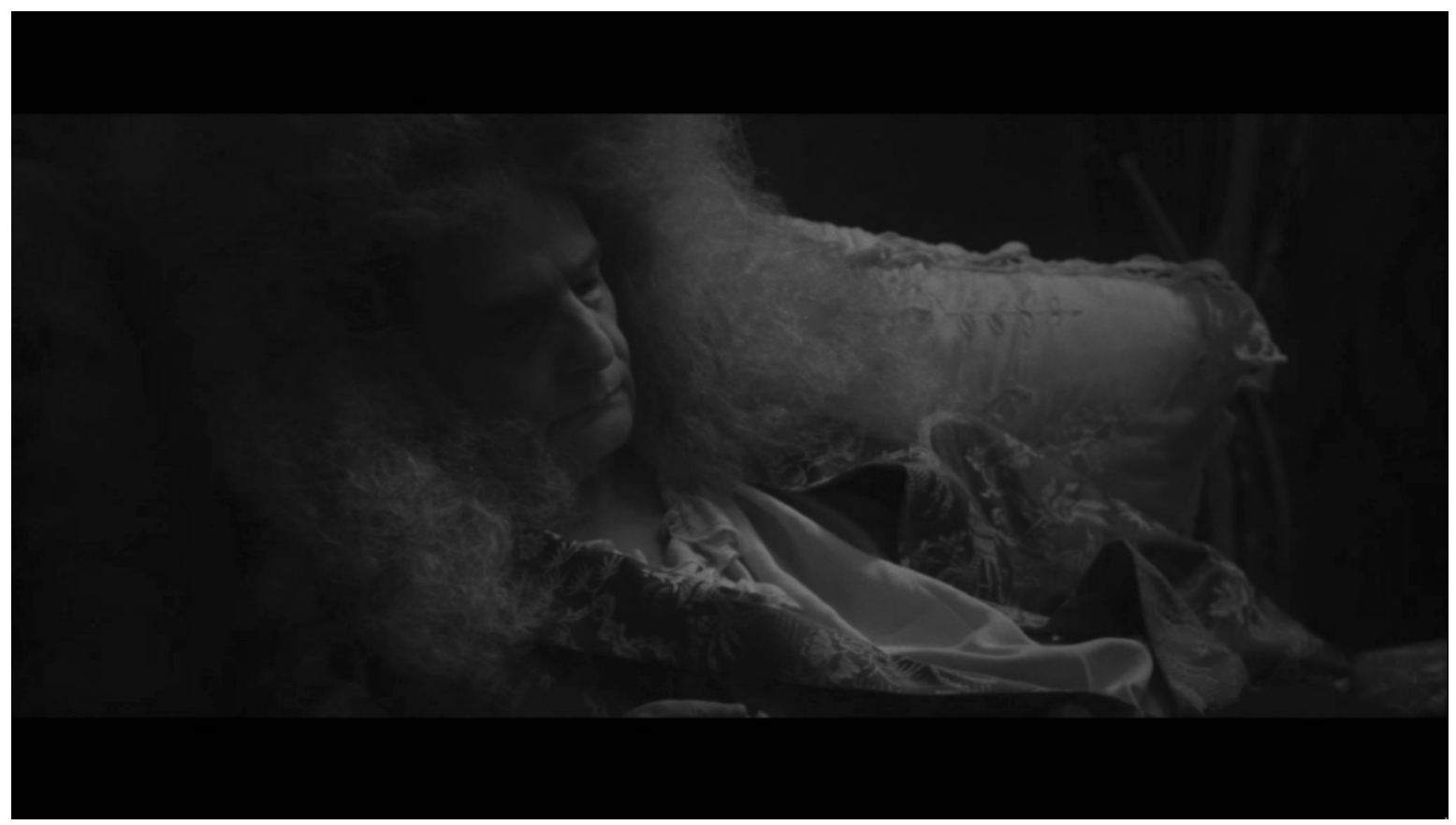

Figure 8. The King is a dying old man. 
INTERNATIONAL JOURNAL OF FILM AND MEDIA ARTS Vol. 3, Nº. 2

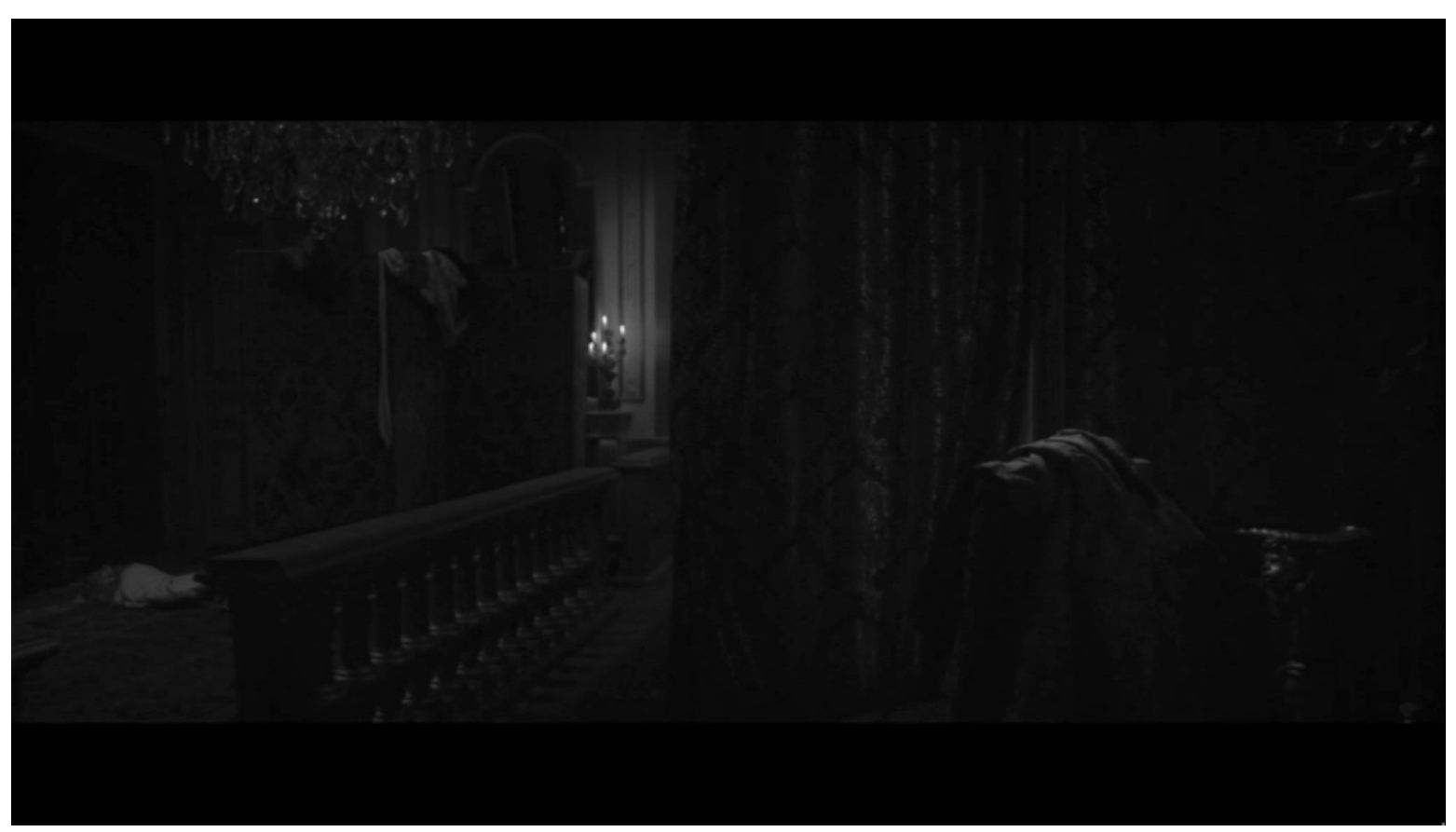

Figure 9. Shadows swallow the private chambers of the King.

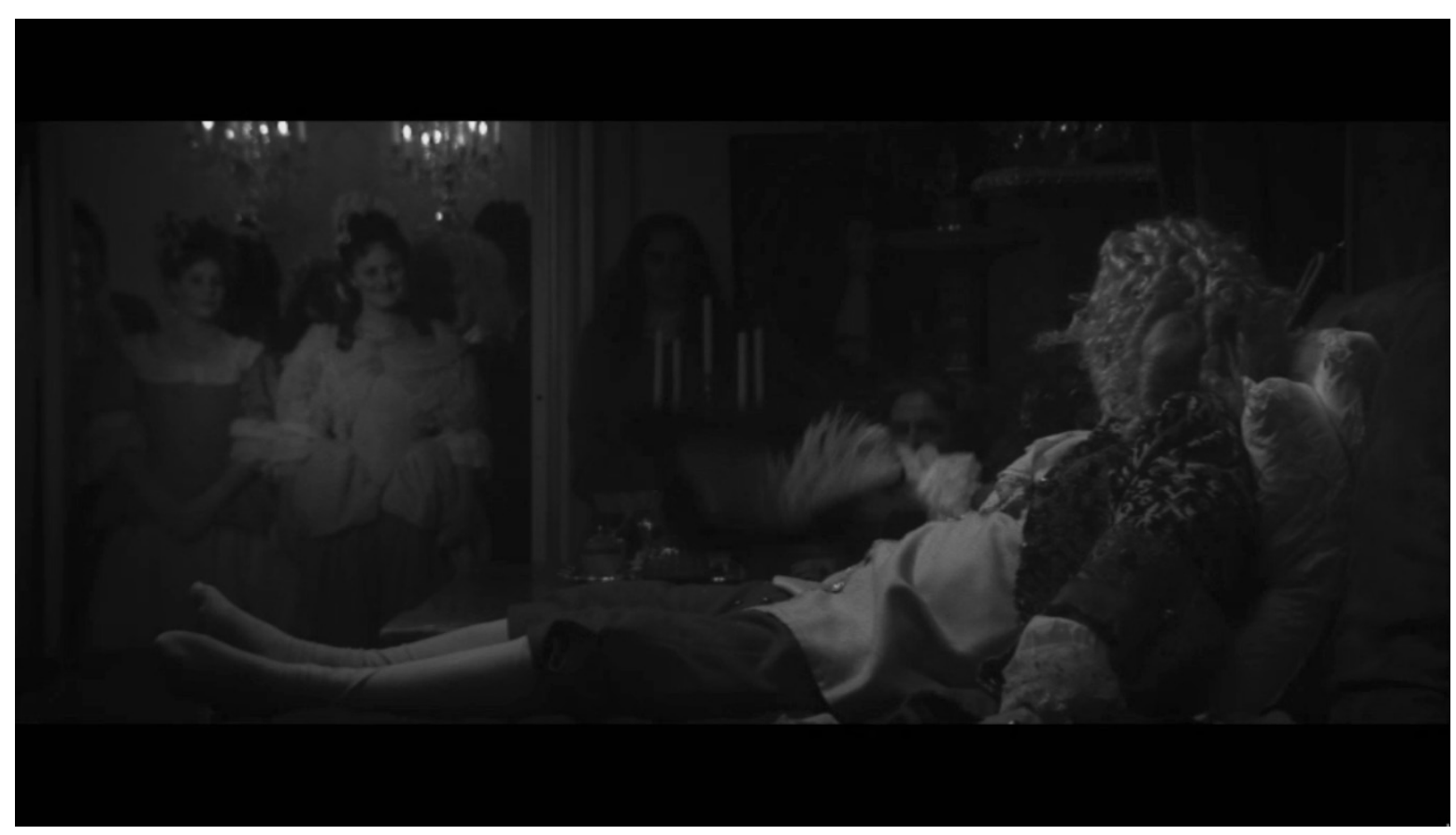

Figure 10. A royal party? 
ALBERT SERRA'S THE DEATH OF LOUIS XIV (2016) ACCORIDNG TO DELEUZE'S CONCEPT OF AFFECTION-IMAGE LKHAGVADULAM PUREV-OCHIR

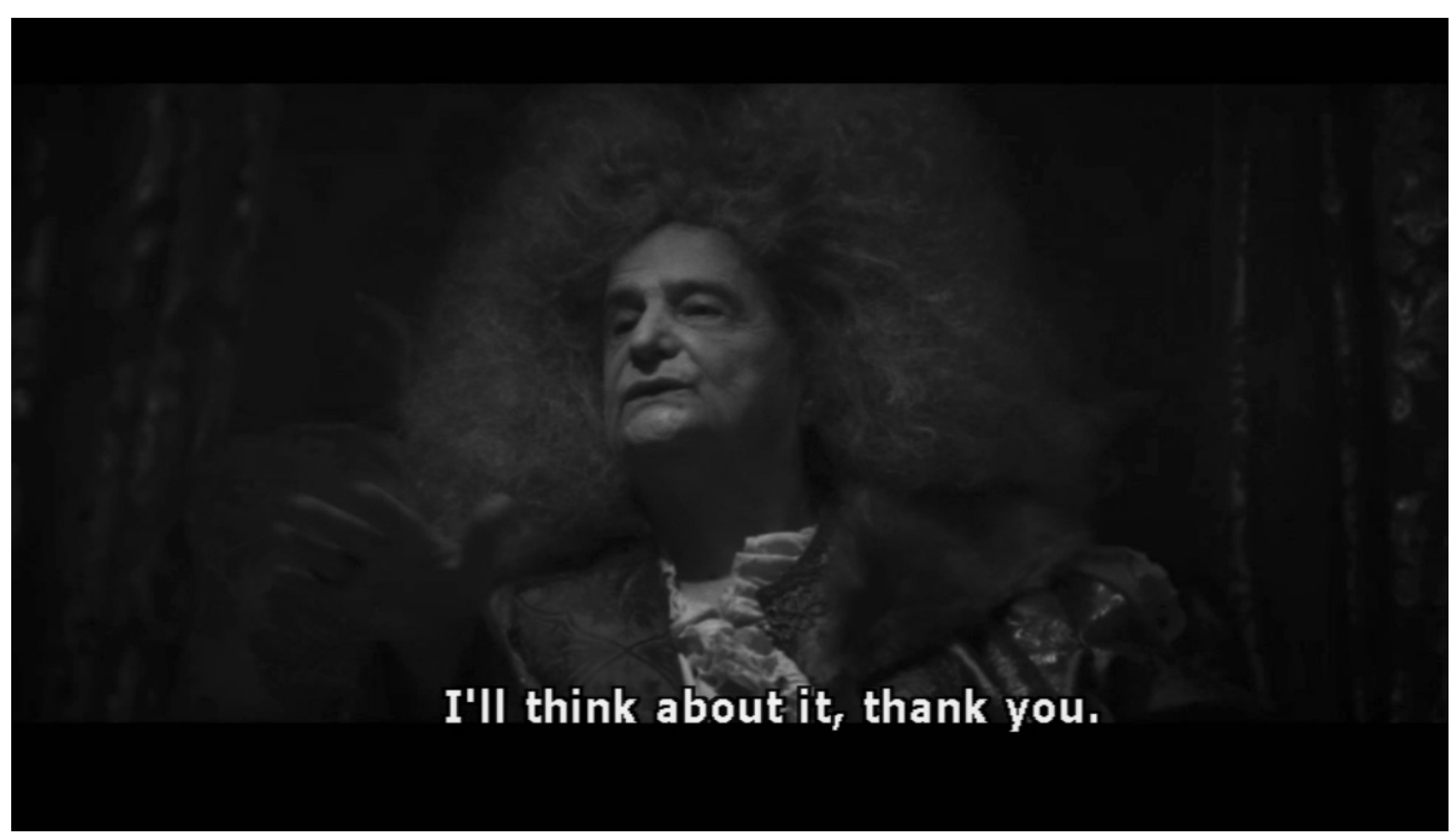

Figure 11. A business meeting in darkness... 
to God. In those times, it was customary for kings to exaggerate their sins in an act of piety (BLUCHE, 1990, 890). Even as the King mentions his regrets in the film, he could be following custom. Louis XIV is, dare I say, the most celebrated and victorious royalty in the history of French monarchy. What is the truth of this scene? Is the King feigning piety, or is he penitent? The answer resides in the affection-image. As the great-grandson runs off, Serra holds the frame on a pensive and motionless King. His chest heaves under labored breathing, and his fingers fumble with a rosary. What is the King thinking? What is he feeling? Through this affection-image, Serra does not show us a king. The image reveals a defeated old man. The image does not communicate the glamor of his royal bedchamber or the glory of the character. The image portrays a private and personal moment of an old man, perhaps thinking back upon all that he's done and wondering if it was worth it. What we see is a man in a private moment, not the public figure of the King. The image is disconnected from socio-cultural coordinates. We are faced with an affect.
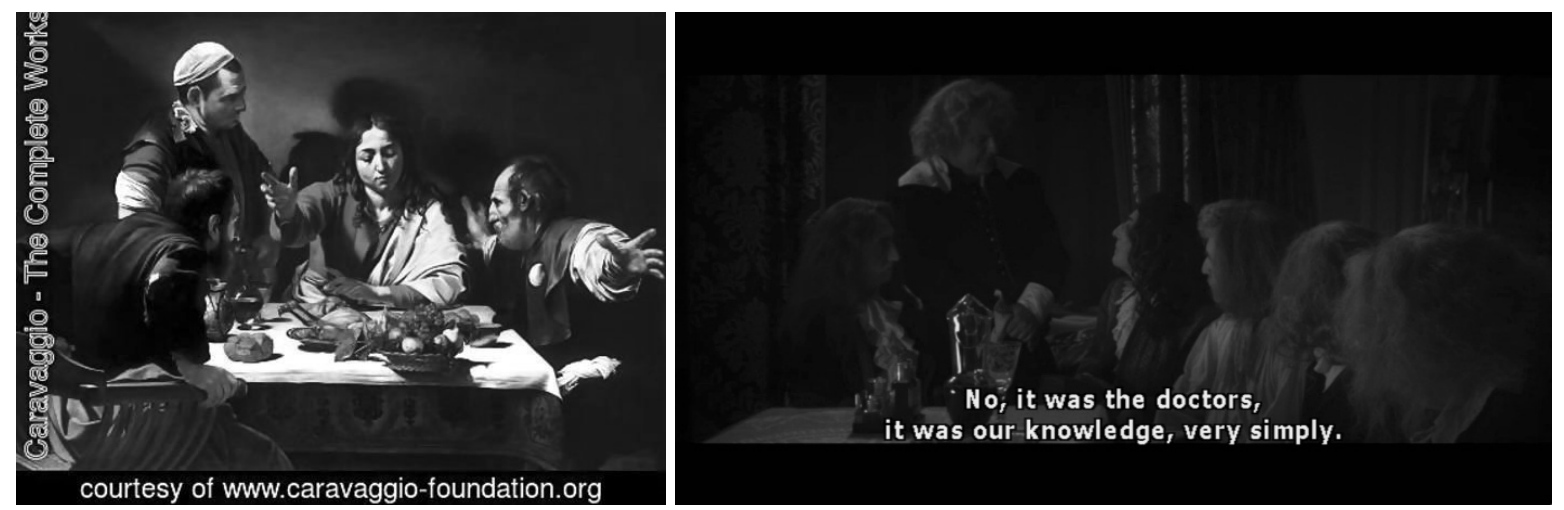

Figure 13. Caravaggio's 'Supper at Emmaus' and a still from 'The Death of Louis XIV'
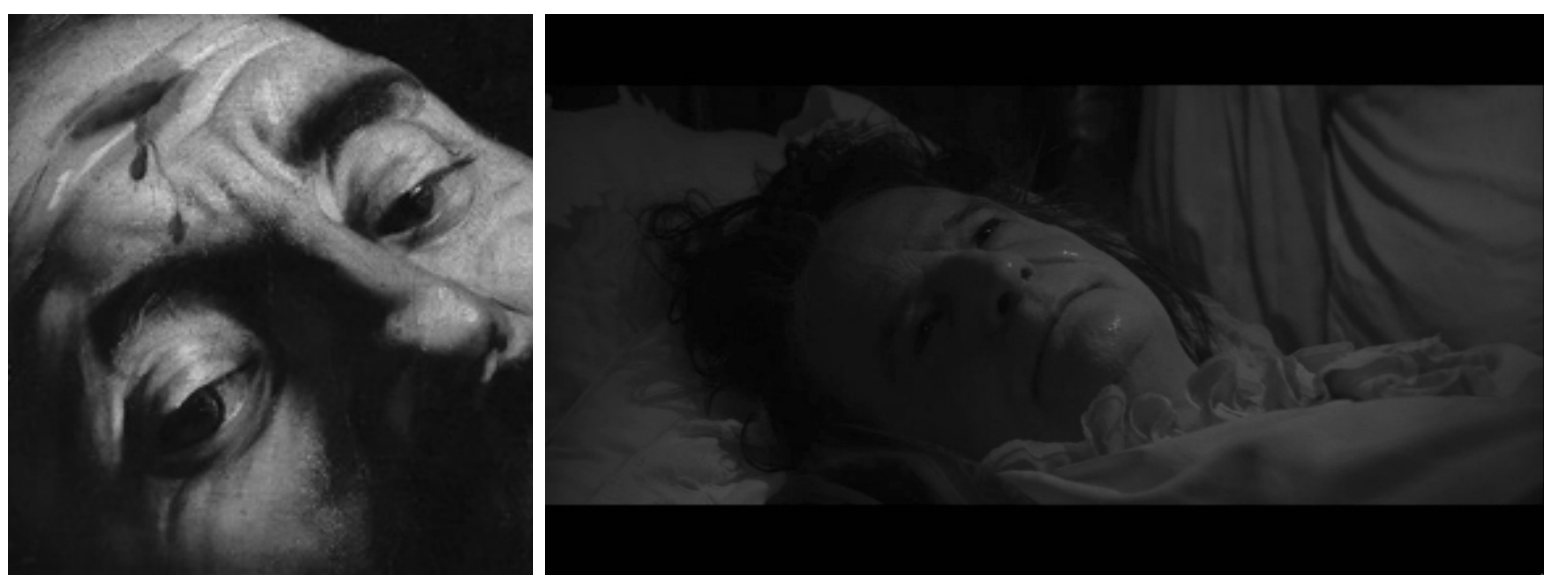

Figure 14. Caravaggio's ‘David and Goliath' and a still from 'The Death of Louis XIV' 


\section{Affection-image as any-space- whatever}

Director Albert Serra sets The Death of Louis XIV mostly in the claustrophobic space of the King's bed chamber. A play of ominous shadows and subtle lighting transforms the royal bed chamber of Louis XIV into an uncharacteristic, atmospheric environment. Serra creates an 'any-death-bed-of-anybody', whereby the mise-en-scene works to 'affect', not inform. Deleuze explains, "We now say that there are two kinds of signs of the affection-image...: on the one hand the power-quality expressed by a face or an equivalent; but on the other hand, the power-quality presented in any-space-whatever" $(1997,110)$.

The glamour, the wealth, and the brilliance, i.e. the lightness and the brightness, of $18^{\text {th }}$ century French royal court life is hardly seen in The Death of Louis XIV.

Serra diminishes the significance of the Palace of Versailles by shrouding its corners in darkness. "... a space full of shadows, or covered with shadows, becomes any-space-whatever" (DELEUZE, 1997, 111). The shadows and the darkness of the environment strip the King's bedchamber of its space-time coordinates. The geographical and historical significance of the space is effaced to become the any-space-of-any-sick-person. The space lacks perspective and is two-dimensional. The claustrophobia is created by firstly, the camera that focuses on the immobile King, and secondly, by the shadows that cover all corners. "The shadow extends to infinity. In this way it determines the virtual conjunctions which do not coincide with the state of things or the position of characters which produce it..." (DELEUZE, 1997, 112) Whether it be a lively party with the court ladies or a business meeting concerning the building of a new bridge (during the day), the spaces are dark and brooding.

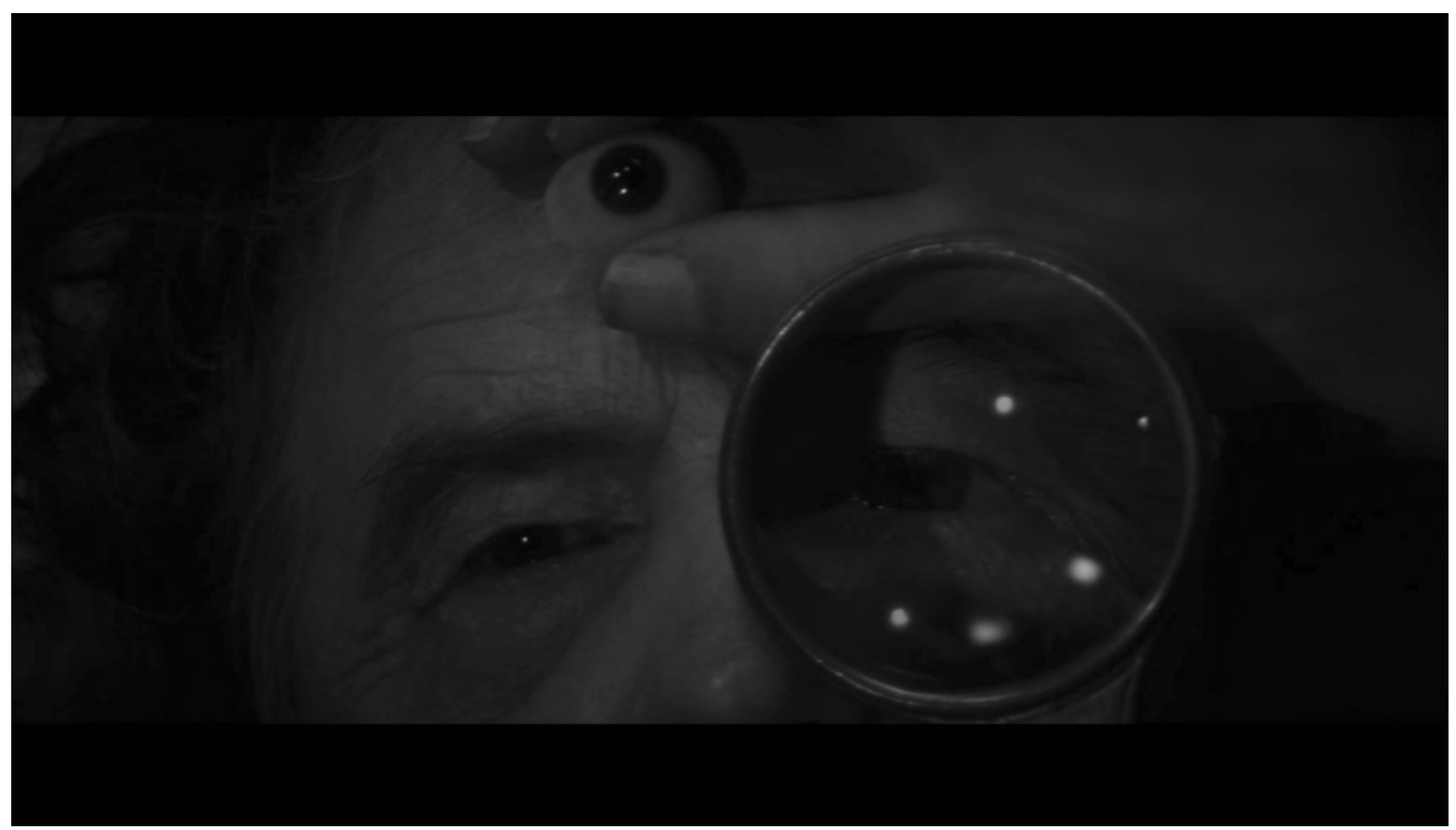

Figure 15. Fragmentation of the King's body 
In the above images one could argue that the viewer can still understand where the film is set and point out its socio-cultural determinates. Deleuze explains,

"Any-space-whatever is not an abstract universal, in all times, in all places. It is a perfectly singular space, which has merely lost its homogeneity, that is, the principle of its metric relations or the connection of its own parts, so that the linkages can be made in an infinite number of ways" $(1997,109)$.
In other words, in any-space-whatever, there are no causal relationships between the spaces. There are no actions that connect the spaces together. The spaces in The Death of Louis XIV are tough to figure out immediately because there is no causal link between the scenes or the spaces. The viewer has to think about in which room the scene is taking place and what is happening in the scene because there are no events which carry on through the spaces in a linear fashion. Each space has an action such as an evening party, a meeting with the doctors, or a meeting with the King's great-grandson. However, no action runs consecutively from space to space. The spaces are not connected with action sequences; therefore, the scenes can be edited in a myriad of ways. The sickness of the King connects all scenes together but the sickness itself is not an action but a situation. The spaces in The Death of Louis XIV, although singular, are not determined through characters and their actions.

The most effective use of any-space-whatever happens in the moments which portray the King alone, battling the faceless enemy that is death. Shrouded in almost complete darkness, the King is in bed, writhing from pain, calling out for water in a frail voice. The valet slowly advances towards the King, with a glass of water. The King slaps

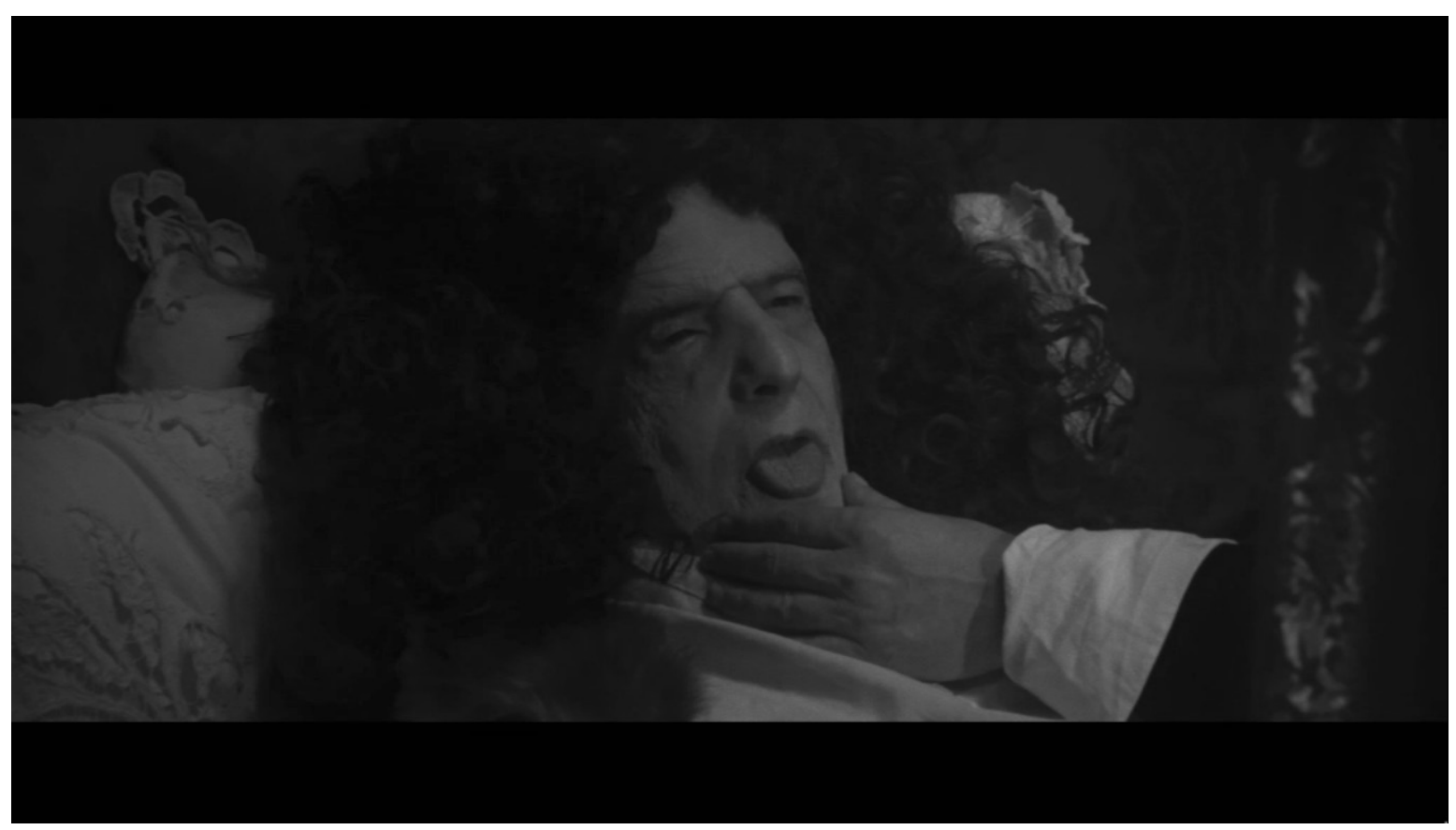

Figure 16. The King as object of survey 
ALBERT SERRA'S THE DEATH OF LOUIS XIV (2016) ACCORIDNG TO DELEUZE'S CONCEPT OF AFFECTION-IMAGE LKHAGVADULAM PUREV-OCHIR

the tray away, for as sick as he is, the King will drink water from a crystal glass only! The King answers back to death in the only way he can, which is to exercise his executive power over his courtiers. The camera hardly reveals anything, save for a writhing mass of body or a few glistens of sweat on the King's face.

Death, as signified by the engulfing shadows, surrounds the King. And the only way the King can fight back is to continue to be King. In the final scenes of the film, the King is barely lucid; he orders what shall become of his body parts after death. One could argue that this final attempt at controlling his own body is an attempt at containing the

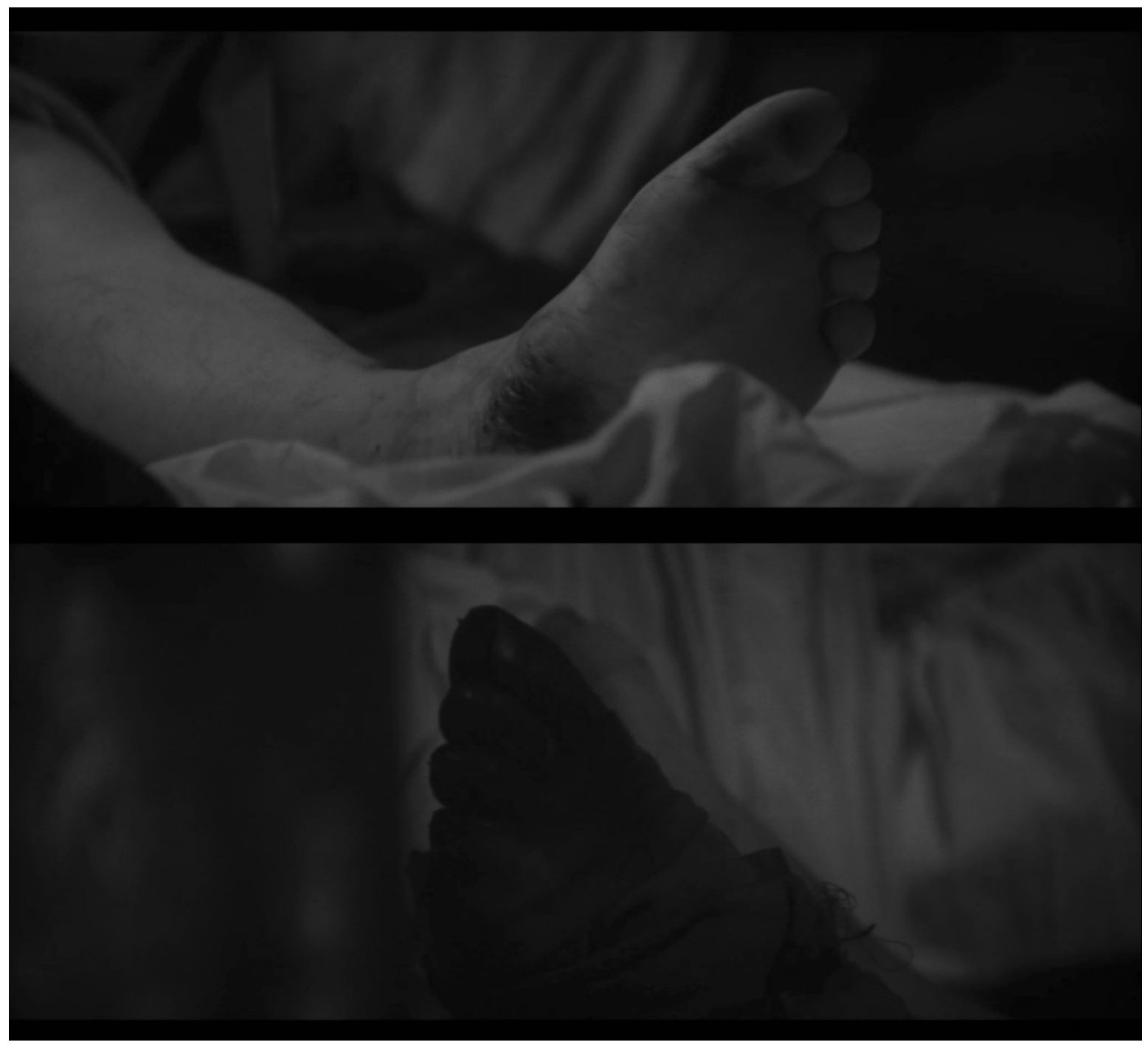

Figure $17 \& 18$. Fetishistic fragments of the King's body. 
power of death. One could also argue that it is a ritualistic and meaningless activity that signifies failure.

Ironically, the $18^{\text {th }}$ century in The Death of Louis XIV resembles Caravaggio's paintings rather than, for comparison's sake, $18^{\text {th }}$ century French painting which are spacious, airy, bright, and have great depth of field. It is safe to postulate that Serra did not intend to make a realistic portrayal of $18^{\text {th }}$ century French court life, but rather, an affective portrayal of death, its banality and inevitability, even in the royal palace of Louis XIV.

\section{Affection-image as degradation to impulse-image}

In The Death of Louis XIV, there are many depictions of the King which fail to reveal an affect and instead linger as impulse-image. The subjective body of the King slowly degrades into pure objective symbol as the film progresses. These impulse-images depict the slow degradation of the body of Louis XIV, especially during the endless examinations of the King's body and in the close-up shots of the King's rotting flesh.

But first, what is an impulse-image? Deleuze defines impulse-image in relation to affection and action image:
"An impulse is not an affect, because it is an impression in the strongest sense and not an expression. But neither is it like the feelings or emotions which regulate and deregulate behavior. Now we must recognize that this new set is not a mere intermediary, a place of transition, but possesses a perfect consistency and autonomy, with the result that the action-image remains powerless to represent it, and the affection-image powerless to make it felt" $(1997,123)$.

As we can see, the impulse-image is no longer affection-image but is not

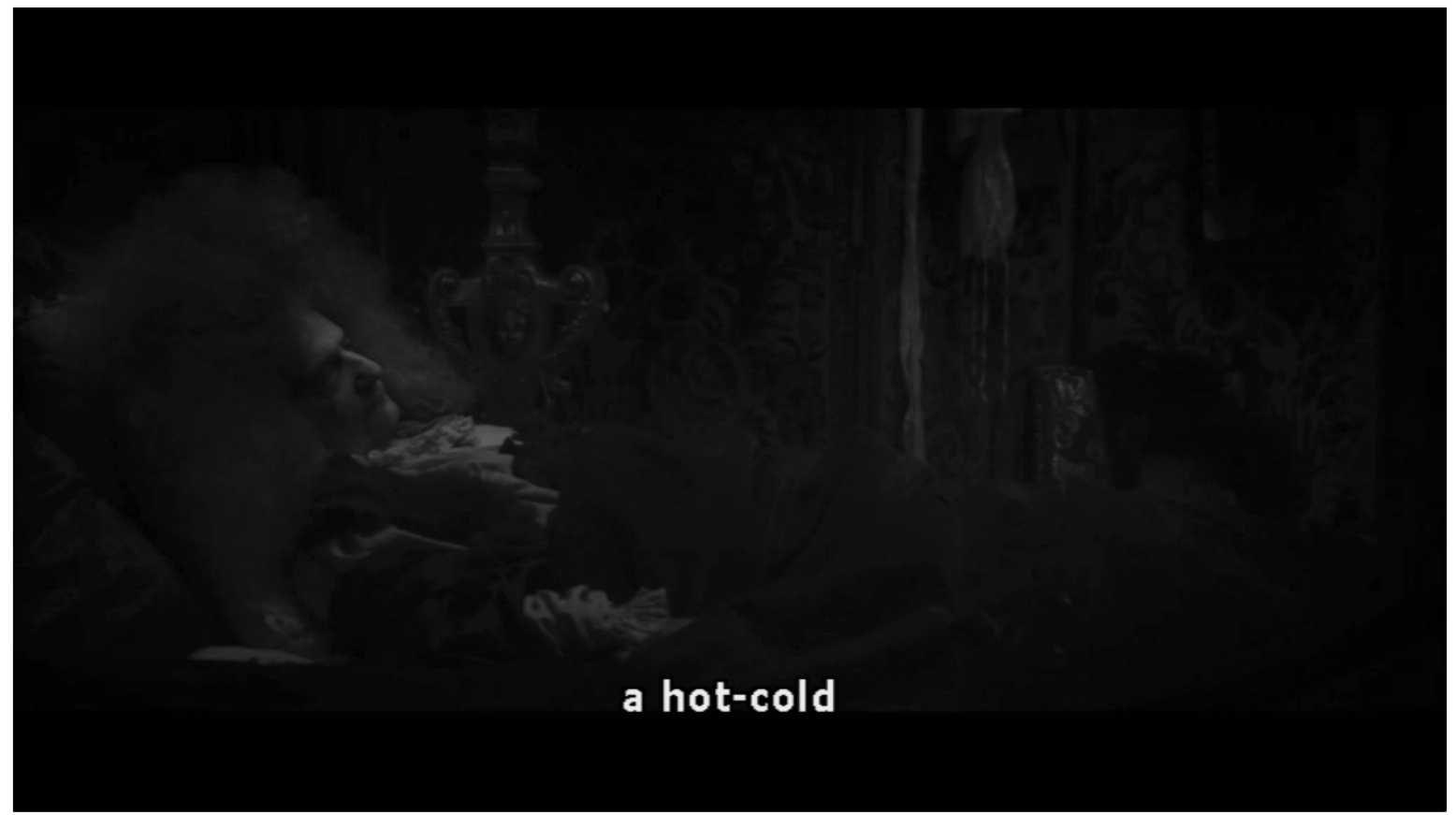

Figure 18. Ultimately, even the mind degrades. 
ALBERT SERRA'S THE DEATH OF LOUIS XIV (2016) ACCORIDNG TO DELEUZE'S CONCEPT OF AFFECTION-IMAGE LKHAGVADULAM PUREV-OCHIR

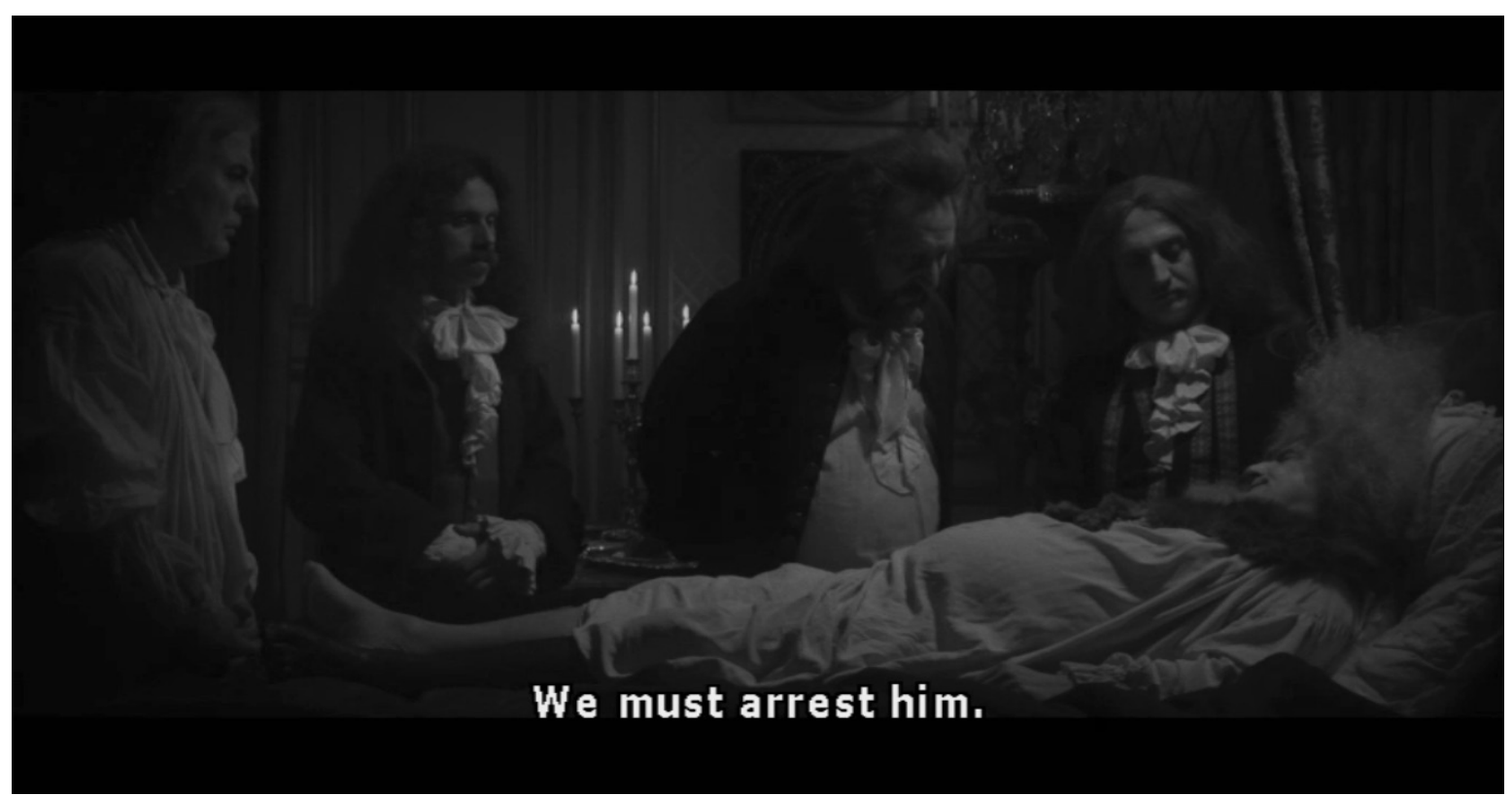

Figure 19. Doctor Fagon asks an unconscious King for the punishment of Doctor Lebrun.

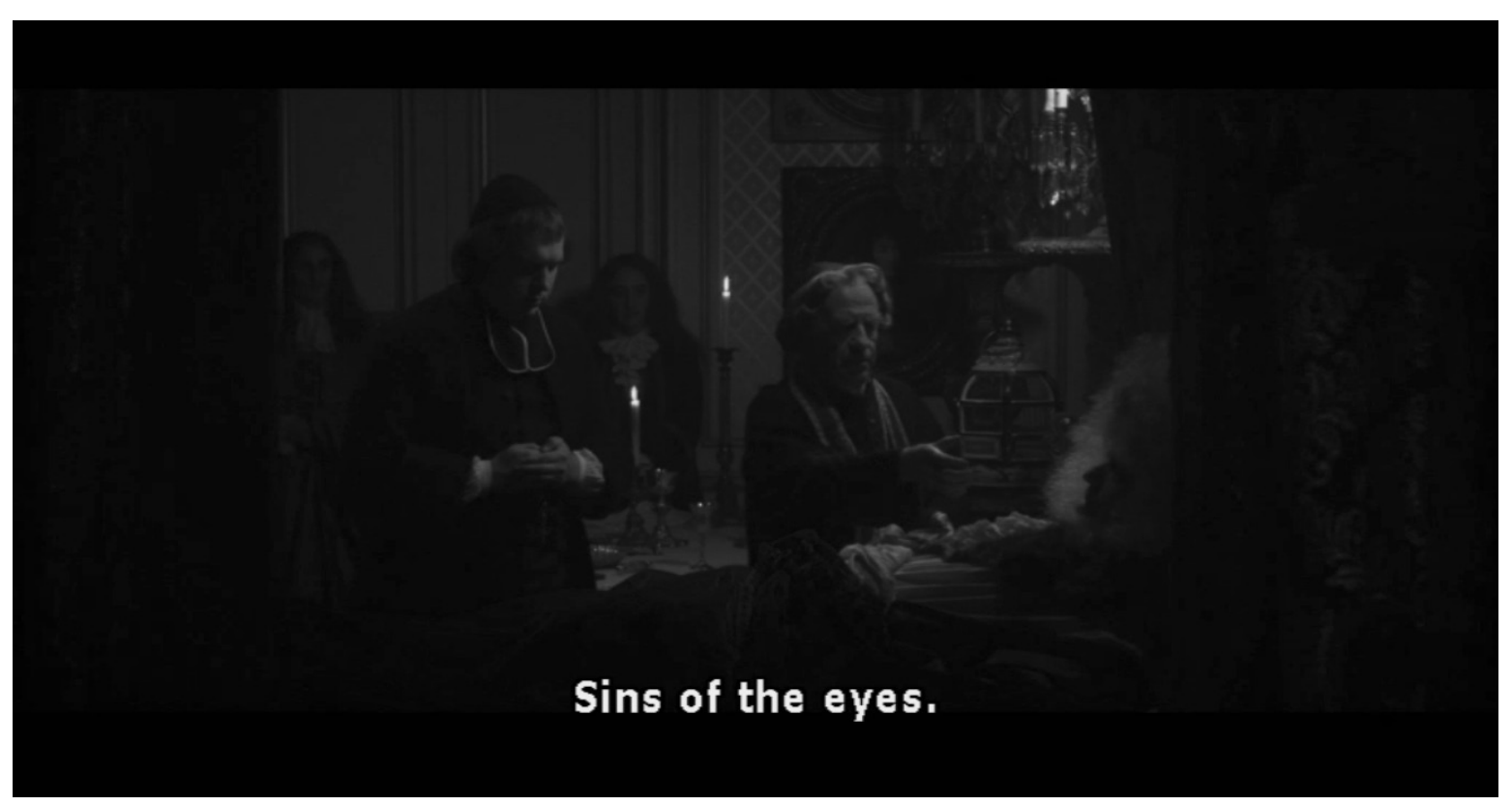

Figure 20. Meaningless rites. 
INTERNATIONAL JOURNAL OF FILM AND MEDIA ARTS Vol. 3, №. 2

yet action-image. The close-up shots of the King's leg, especially as it rots until it becomes a black mass, are not affection-images. They do not reach past the actuality of the image - the gangrene spot on the foot, the blackening leg - to reach a virtuality of thought, emotion, and expression. They also do not act within the frame of the action-image; they do not lead to or result in any other situation. These images are in the middle ground between affect and action neither expressive nor active. They are pure symbols. Deleuze explains: "The impulse-image has in fact two signs: symptoms, and idols or fetishes" $(1997,125)$.

Symptoms are the modes of behavior of characters that do not actualize as actions (much like the behavior of the doctors in The Death of Louis XIV - more on this later). Idols/fetishes are the representation of fragmentation of bodies and subjects. In The Death of Louis XIV, the symptomatic behavior of the doctors always result in fragmentation of the King's body. In other words, certain close-up shots of the King's face and his body during medical examinations are impulse-images because they are 'objectifying' symbols that fragment the subjectivity and subjective power of the King.

The above impulse-images are what Deleuze calls fetishistic fragments. Even though they are traditionally 'closeup shots', they are not affection-images. They do not impart a quality of power or

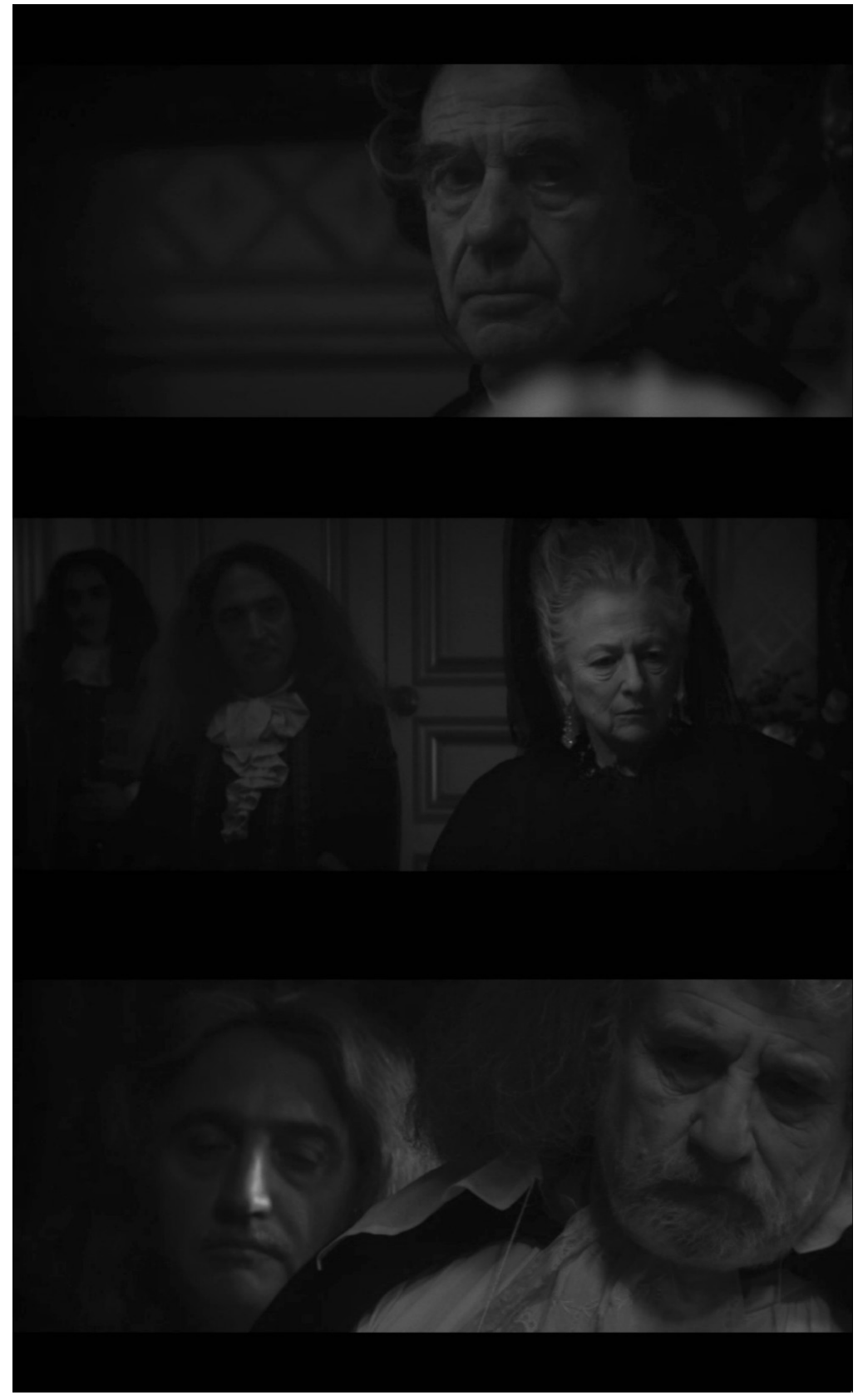

Figures $21,22,23$. Violence of the gaze of others. 


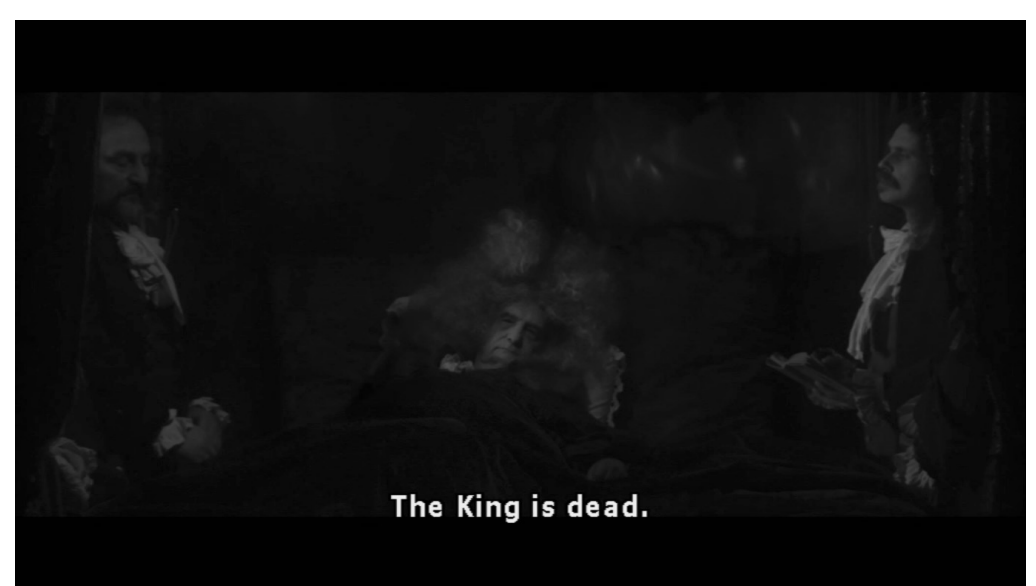

Figure 24. “...all the parts converge in an immense rubbish-dump or swamp, and all the impulses in a great death-impulse..."

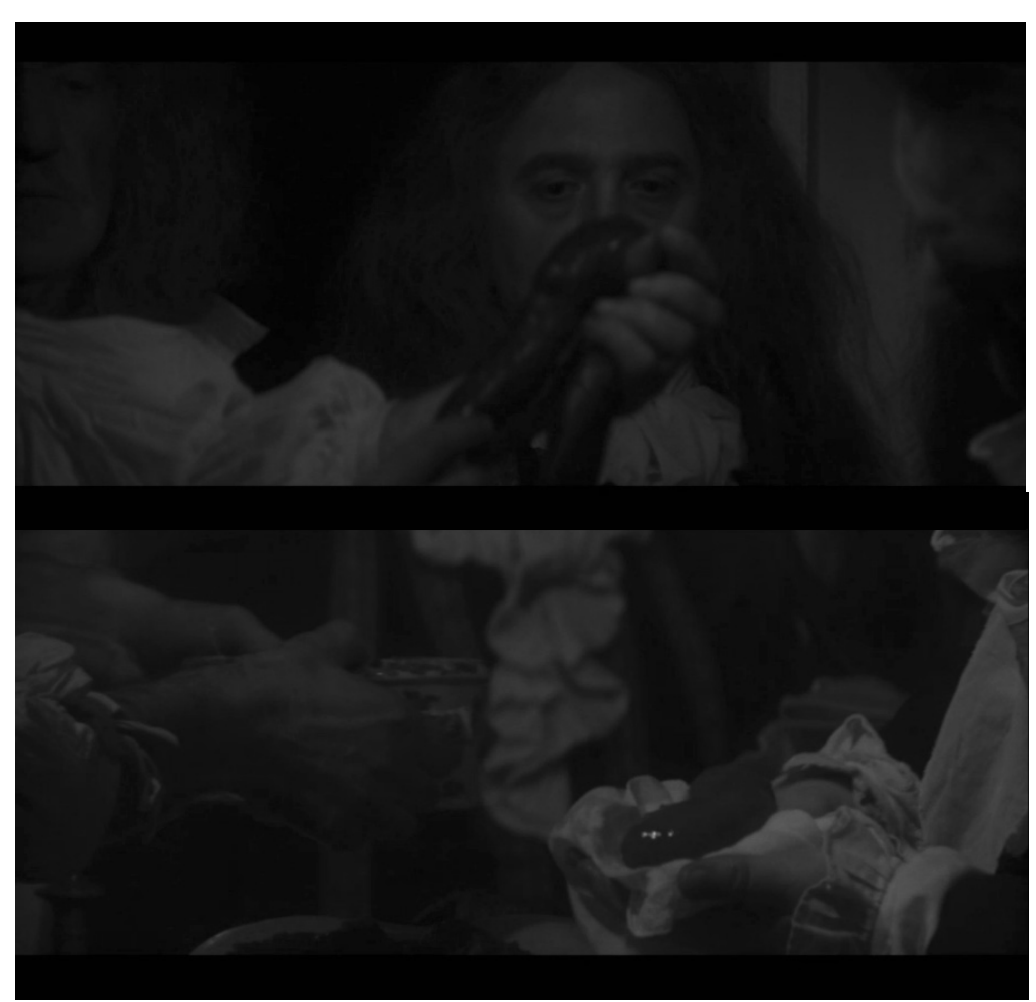

Figures $25 \& 26$. What's left of the King. expression. They are pure impressions or symbols without any active or affective power. Deleuze adds that the impulse-image is "...undoubtedly the only case in which the close-up effectively becomes partial object... The impulse is an act which tears away, ruptures, dislocates" $(1997,128)$. The impulse-image is not a quality or power as expressed; it is the literal image of a broken and severed body or subject. It is magnification and dismemberment. It is a fragmented and fractured image.

The King's body is examined, scrutinized, and fragmented by the doctors, resulting in the degradation of his image, and subsequently his power. The King's body becomes a mummy. "The object of the impulse is always the 'partial object', or the fetish: a haunch of meat, a raw morsel, a scrap, a woman's briefs, a shoe" (DELEUZE, 1997, 128). The etymology of the word fetish originates from the Portuguese feitiço, or "'charm, sorcery, allurement,' noun use of an adjective meaning 'artificial'" (ONLINE ETYMOLOGY DICTIONARY, n.d.). It is illustrative of how the Sun King, the earthly embodiment of God, turns into a pagan object of worship. The King loses all executive power in these images and becomes a fetishistic (symbolic) object. $\mathrm{He}$ is still the King but only in name.

Moreover, the exhausting examination by the doctors and the scrutinizing gazes of the doctors and courtiers are 
all impulse-images because they are 'symptoms'. The doctors' actions do not actualize to a new/restored situation; therefore, the doctors' actions are only modes of behavior. Modes of behavior are ritualistic and repetitive actions, actions that are ineffective. At the end, The Death of Louis XIV can be described as a two-hour anatomical survey of the King's body. The doctors do nothing more than endlessly examine and scrutinize the King's body. Therefore, all actions of doctors, including the fragmentation of the King's body, are impulse-images.

At the end of the film, the King's leg is a protruding black extension from his body.
The King's mind also starts to degrade. He demands 'a hot-cold pot of poultry' which the doctors deem as "good news. He's getting his strength back". This is a degradation and entropy characteristic of the impulse-image.

Serra creates pure irony within the frame-work of the impulse-images in The Death of Louis XIV. The activities of the doctors are purely ritualistic and redundant. According to Deleuze, repetition is a sign of entropy and degradation (1997, 133). The doctors continue to force feed the King up until his last breath. The repetitive actions of the doctors and the religious ceremonies carried out by the priests and cardinals become a perversion because of their ineffectiveness and senselessness. The redundant 'treatments' that start with Doctor Fagon continue with the arrival of the Sorbonne doctors and, finally, with the charlatan Doctor Lebrun who succeeds in feeding the King 'bull's sperm and blood with frog fat'. These doctors who so effortlessly belittle each other as impotent, cannot themselves create effective solutions: at the end, their actions implode (impulse images implode while action-images explode). As the King's body decays, they realize that they must find a culprit lest they will be held accountable for the King's death. When the King is barely lucid and taking his last breaths, the court doctor

\section{Gentlemen, we'll do better next time.}

Figure 27. Final image of film 
Fagon succeeds in sanctioning the punishment by death of the charlatan Doctor Lebrun. This action, which is actually a degradation, is an impulse-image. It is an elementary impulse for survival.

As I see it, Serra portrays a certain kind of violence with the impulse-images in the film. The meaningless and repetitive rites and rituals imposed on the dying King are brutal in their normalcy and banality. The King is trapped within these impulses. One can postulate that the set-up/mise-en-scene of the courtiers around the King and the images of their faces, particularly their gazes, are impulse-images. In a sense, the King becomes their prey. Everyone hovers over the King like predators. His body is objectified by their gazes.

Even as these images of the courtier's faces are 'close-ups' in the traditional sense, in the Deleuzian sense, they are impulse-images, which work neither to affect nor to act. These impulse-images frame a downward spiral to degradation. In certain scenes where the recumbent King is literally surrounded by people, this framing is even more evident. Deleuze describes the framework of the impulse-image:

"... made up of outlines and fragments, heads without necks, eyes without faces, arms without shoulders, gestures without form. But it is also the set which unites everything, not in an organization, but making all the parts converge in an immense rubbish-dump or swamp, and all the impulses in a great death-impulse. The [impulse] world is therefore both radical beginning and absolute end; and finally it links the one to the other, it puts the one into the other, according to a law which is that of the steepest slope. It is thus a world of a very special kind of violence (in certain respects, it is the radical evil) ... $(1997,124)$.

In other words, the ultimate impulse is the death-impulse, and all decay lead to it. The impulse-image, with its meaningless and ritualistic behaviors and fetishistic fragments, is the symptom and symbol of death. Through these impulse-images in the film - the shots of the King's fragmented body as well as the scrutinizing gazes of the crowd surrounding him - Serra draws a conclusion about the violence of death. As Deleuze points out, the impulse-image depicts 'a steep slope', in the case of The Death of Louis XIV, a steep slope to death. The final gruesome images of the film are the disemboweled organs of the King's corpse. The doctors comment on the size and length of the colon and the spleen. The King is literally reduced to his body parts.
The last line of The Death of Louis XIV sums up the film and the message Serra wishes to relate with the aesthetic arrangement of his affection-images in relation to action and impulse images:

In this final image, death loses even its affect, its virtual power, and degrades to a medical procedural: 'Gentlemen, we'll do better next time,' says the doctor. No one, not even the absolute power that is King Louis XIV, can escape the inevitability, the violence and the banality of death.

\section{Conclusion}

Albert Serra's The Death of Louis XIV makes a wry and refreshing commentary on death. In stark contrast to the glorification and melodramatization of death of 'important people' in films, Serra chooses to focus and retain his camera on the slow decay that is death with which no one, not even Louis XIV, can fight. For Serra, death is imprisonment, castration, decay, degradation of the body, and a banality of rites.

The affection-images, particularly the face of King Louis XIV, in relation to other images in the film, allow Serra to express the most impersonal and universal truths about life and death. Deleuze suggests a way to make connections between movement-images: "We must always distinguish power-qualities in themselves, as expressed by a face, faces or their equivalents (affection-image 
of firstness) and these same power-qualities as actualized in a state of things, in a determinate space-time (action-image of secondness)" (1997, 106). This study applies this method by determining the power-quality of the affection-images in the film within the space-time of failed action-images and degraded impulse-images. The aesthetic arrangement of movement-images in The Death of Louis XIV all serve to reveal death as a lived experience. The film suggests that death is not one moment or one instance when a person ceases to live. Death is a series of reflective moments, continuous and fluid, which destroys and deconstructs not only the physical body, but also the sociopolitical and cultural coordinates of one's life. The face of Louis XIV reflects this process of reflection, redefinition, and reexamination of one's lived life.

As I see it, Deleuze's concept of affection-image is, through its form and content, a search for meaning and an attempt at constructing truth (in opposition to the role of action-images which is to construct reality). The affection-image aims to express experience and consciousness on a cinematic level. Through the affection-image, cinema thinks on itself and reaches for the plane of metaphysics.

Finally, writing this study has led me to conclude that Deleuze's philosophy has great practical implications for many different areas of filmmaking. I believe that, aside from being a philosophical framework for film theoricians and film critics to analyze films, Deleuze's terminology have the potential to be a constructive framework for a new way of approaching writing and directing. It is my hopes to continue my studies along the lines of 'Deleuzian screenwriting' in the future. 


\section{References}

Ashton, Dyrk. 2006. Using Deleuze: The Cinema Books, Film Studies And Effect. (Unpublished doctoral dissertation). Bowling Green: Graduate College of Bowling Green State University. Retrieved from https://etd.ohiolink.edu/rws_etd/document/get/ bgsu1151342833/inline

Aguilar, Carlos. 2017. No Risk of Cliché: The Unorthodox Methods of Director Albert Serra Pay Off in The Death of Louis XIV. MovieMaker Magazine. Retrieved from https://www.moviemaker.com/archives/interviews/the-death-of-louis-xiv-albert-serra/

Balázs, Béla. 1970. Theory of the Film - Character and Growth of a New Art. (Trans. E. Bone) New York: Dover Publications.

Benjamin, Walter. 1969. Illuminations: Essays and Reflections. (Ed. H. Arendt, Trans. H. Zohn) New York: Schocken Books. p.217-52. (original essay from 1935)

Bluche, François. 1990. Louis XIV. (Trans. M. Greengrass). London: Franklin Watts. (original work published in 1986)

Deleuze, Gilles. 1997. Cinema 1: The Movement-Image. (Trans. H. Tomlinson \& B. Habberjam) Minneapolis: University of Minnesota Press. (Original work published in 1983)

Doanne, Mary Anne. 2008. Scaleand the Negotiation of "Real" and "Unreal" Space in the Cinema. NTU Studies in Language and Literature, Volume 20, doi:10.6153/2008.20.01

Doanne, Mary Anne. 2003. The Close-Up: Scale and Detail in Cinema. Journal of Feminist Cultural Studies, Volume 14, Number 3, p. 89-111. Retrieved from https://muse. jhu.edu/article/50602

Eisenstein, Sergei. 1995. Beyond the Stars: The Memoirs of Sergei Eisenstein. (Trans. W. Powell) London: British Film Institute Publishing.

Epstein, Jean. 1977. Magnification and Other Writings. (Trans. S. Liebman) October. Vol. 3. p. 9-25. Retrieved from https://www.jstor.org/stable/778434? seq=1\#page_ scan_tab_contents

Fairfax, Daniel. 2003. "Everything is dead but the motor still turns": An Interview with Albert Serra. Senses of cinema, Issue 69. Retrieved from http://sensesofcinema. com/2013/feature-articles/everything-is-dead-but-the-motor-still-turns-an-interview-with-albert-serra/ 
INTERNATIONAL JOURNAL OF FILM AND MEDIA ARTS Vol. 3, №. 2

Fetish. (n.d.) In Online Etymology Dictionary. Retrieved from https://www.etymonline. com/word/fetish

Gish, Lillian. 1970. The Movies, Mr. Griffith and Me. New York: Englewood Cliff. p.59-60 Metz, Christian. 1982. Psychoanalysis and Cinema: The Imaginary Signifier. (Trans. C. Britton, A. Williams, B. Brewster, \& A. Guzzetti) p. 196. London: Macmillan Press (original work published in 1977)

Mulvey, Laura. 1975. Visual Pleasure in Narrative Cinema. Screen, vol. 16, (Autumn 1975), p 6-18. Retrieved from http://www.luxonline.org.uk/articles/visual_pleasure_and_narrative_cinema(1).html

Münsterberg, Hugo. 2012. The Film: A Psychological Study. New York: Dover. (original work The Photoplay: A Psychological Study published in 1916)

Parr, Adrian. (Ed.). 2010. The Deleuze Dictionary Revised Edition. Edinburgh: Edinburgh University Press

Roof, Judith. 1999. Close Encounters on Screen: Gender and the Loss of the Field. Genders Journal. Volume 29. Retrieved from https://www.atria.nl/ezines/IAV_606661/IAV_606661_2010_51/g29_roof.html

Rushton, Richard. 2002. What Can a Face Do? On Deleuze and Faces. Cultural Critique, Vol. 51, p.219-237. Minneapolis: University of Minnesota Press. doi:10.1353/ cul.2002.0021

Yepes, Julia. 2017. The Subversive Logic of Albert Serra. Interview Magazine. Retrieved from https://www.interviewmagazine.com/film/albert-serra-the-death-of$\underline{\text { louis-xiv }}$

\section{Films}

Dreyer, C.T. (director). (1928). The Passion of Joan of Arc [motion picture]. France: Société Générale des Film.

Lounas, T. (producer) \& Serra, A. (director). (2016). The Death of Louis XIV [motion picture]. Spain: Andergraun Films.

Waisberg, E. (producer) \& Tarkovsky, A. (director). (1975). The Mirror [motion picture]. Soviet Union: Goskino. 